\title{
Paleoenvironment and biostratigraphy of the Upper Sinemurian (Lower Jurassic) of the Huayacocotla Formation in East-Central Mexico
}

\author{
Carlos Esquivel-Macías, Rita Gabriela León-Olvera, Kinardo Flores-Castro
}

Carlos Esquivel-Macías

galeon10@yahoo.com

Kinardo Flores-Castro

Cuerpo Académico de Ciencias de la Tierra,

UAEH Pachuca, Hidalgo. C.P. 42184

Rita Gabriela León-Olvera

Independent researcher

\begin{abstract}
The Lower Jurassic Huayacocotla Fm. (Upper Sinemurian), was first studied by several American and European geologist during the twentieth century (1948), whom eventually concluded that these rocks were not commercially productive. Consequently, the interest in this unit faded a long time ago. However, studies resumed in the 2000's by Mexican researchers, this time including a wide range of paleontological, paleoenvironmental, paleoecological, geologic, and structural aspects, incorporating taphonomic, petrologic and geochemical techniques. They concluded that the Huayacocotla Fm. is not a condensed sequence, but can be better regarded as a single unit, including several facies rather than a complex unit of several formations. Today, it is well known that the Huavacocotla Fm. was deposited in a semi-restricted back arc paleobasin, with suboxic to euxinic conditions. Its protolith of igneous intermediate composition reveals tectonic features related to the Pangea collision phase and the first stages of the Gulf of Mexico opening. The paleobasin with high rate of sedimentation, generated this sequence siliciclastic, simultaneously with the process of expansion of the Gulf of Mexico. The modern biostratigraphical analyses developed in the 2000's, accurate the biostratigraphic zonation proposed by Burckhardt and Erben. These new studies revealed that the deposition of the Huavacocotla Fm. spanned several Late Sinemurian diverse chronozones, especially Oxynotum, Densinodulum, and Raricostatum subzones. Nevertheless, some local divergences with respect to the standard biozonation were noticed, and these anomalies are tentatively explained to be the result of Early Sinemurian homotaxial events. There is a gap in the Lower Obtusum faunas, but the presence of Lower Sinemurian deposits was reported from at least one outcrop. This Jurassic field trip guide was written to lead and encourage interested researchers in this field to contribute to this subject, and maybe other related topics, as well as to encourage academic discussions about the knowledge of Early Jurassic marine paleobasins, in the context of the 10th International Jurassic Congress.
\end{abstract}

Keywords: Jurassic, Sinemurian, Huayacocotla, Mexico, Biostratigraphy.

\section{RESUMEN}

La Formación Huayacocotla del Furásico Inferior (Sinemuriano Superior) fue estudiada por varios geólogos norteamericanos y europeos durante el siglo veinte (1948), que concluyeron que estas rocas no eran comercialmente productivas. En consecuencia el interés en ellas decayó. Durante la primera década de los 2000's se retoma su estudio ahora en el aspecto paleontológico y paleoambiental a cargo de investigadores mexicanos, incorporando conceptos y técnicas de tafonomía, geoquímica y petrología, lo cual permitió encontrar que se trata de una secuencia desarrollada (sensu no condensada), que en principio parecía dividida en varias formaciones y que resultaron ser facies de una sola Formación. Ahora se sabe que la Fm. Huayacocotla representa una paleocuenca intrarco semirestringida, con fondos de condiciones subóxicas a euxínicas; cuyo protolito de composición ígnea intermedia delata rasgos tectónicos involucrados en la fase de colisión de la Pangea y en las primeras fases de la apertura del Golfo de México. La paleocuenca con alta tasa de sedimentación, generó esta secuencia siliciclástica, simultáneamente con el proceso de expansión que originó al Golfo de México. Desde el 2000 también se elaboraron trabajos sobre bioestratigrafia en estas localidades, que afinan la zonación bioestratigráfica indicada en términos generales por Burckhardt y Erben al principio del siglo veinte. Esto evidenció que esta secuencia se desarrolló durante las cronozonas del Sinemuriano Superior centradas alrededor de las Zonas de Oxynotum, Densinodulum y Raricostatum; sin embargo, numerosas anomalias faunisticas se explican como eventos homotaxiales relacionados al Sinemuriano Inferior, con una marcada interrupción de la fosilización durante la zona Obtusum. La presente guía se formula como apoyo para conducir en un recorrido de campo a investigadores interesados en el intercambio de información y colaboración que permitan ampliar estos conocimientos a otras secciones jurásicas, tanto de esta paleocuenca marina como del mundo, en el marco del $X$ Congreso Jurásico Internacional.

Palabras clave: Jurásico, Sinemuriano, Huayacocotla, México, Bioestratigrafía.
BOL. SOC. GEOL. MEX. 2017

VOL. 69 NO. 3

P. $739-770$ 


\section{Introduction}

\subsection{HUAYACOCOTLA FORMATION}

The Otomí-Tepehua range is located at the southernmost sector of The Sierra Madre Oriental province. Here, the most influential villages are Tenango de Doria, San Bartolo Tutotepec, and Pahuatlán. This place can be reached by Federal Highway 85 from Mexico City to Pachuca, Hidalgo, and then by Federal Highway 130 in the Pachuca-Tulancingo segment. The turn to San Alejo is a few kilometers after Tulancingo. At San Alejo, there is a road leading to Tenango de Doria. From there, the road to San Bartolo Tutotepec be- gins. This range has been studied in 1889 by Felix and Lenk (1889-1899) and later by Böse (1898). Burckhardt (1930) was the first to apply a biozonation in the area (Figure 1).

The Huayacocotla Formation, first proposed by Imlay et al. (1948), was referred to the Early Jurassic based on the ammonite stratigraphy of the region. Likewise, they described the main lithology, with silt-sandy variants. The faunal content was detailed by Erben (1956), who recorded more than 100 taxa, including 52 new species, and described thick siliciclastic deposits averaging $400-500 \mathrm{~m}$ in his Vinasco river type locality. Later, Schmidt-Effing (1980) and Schlatter and Schmidt-Effing (1984) defined four units around

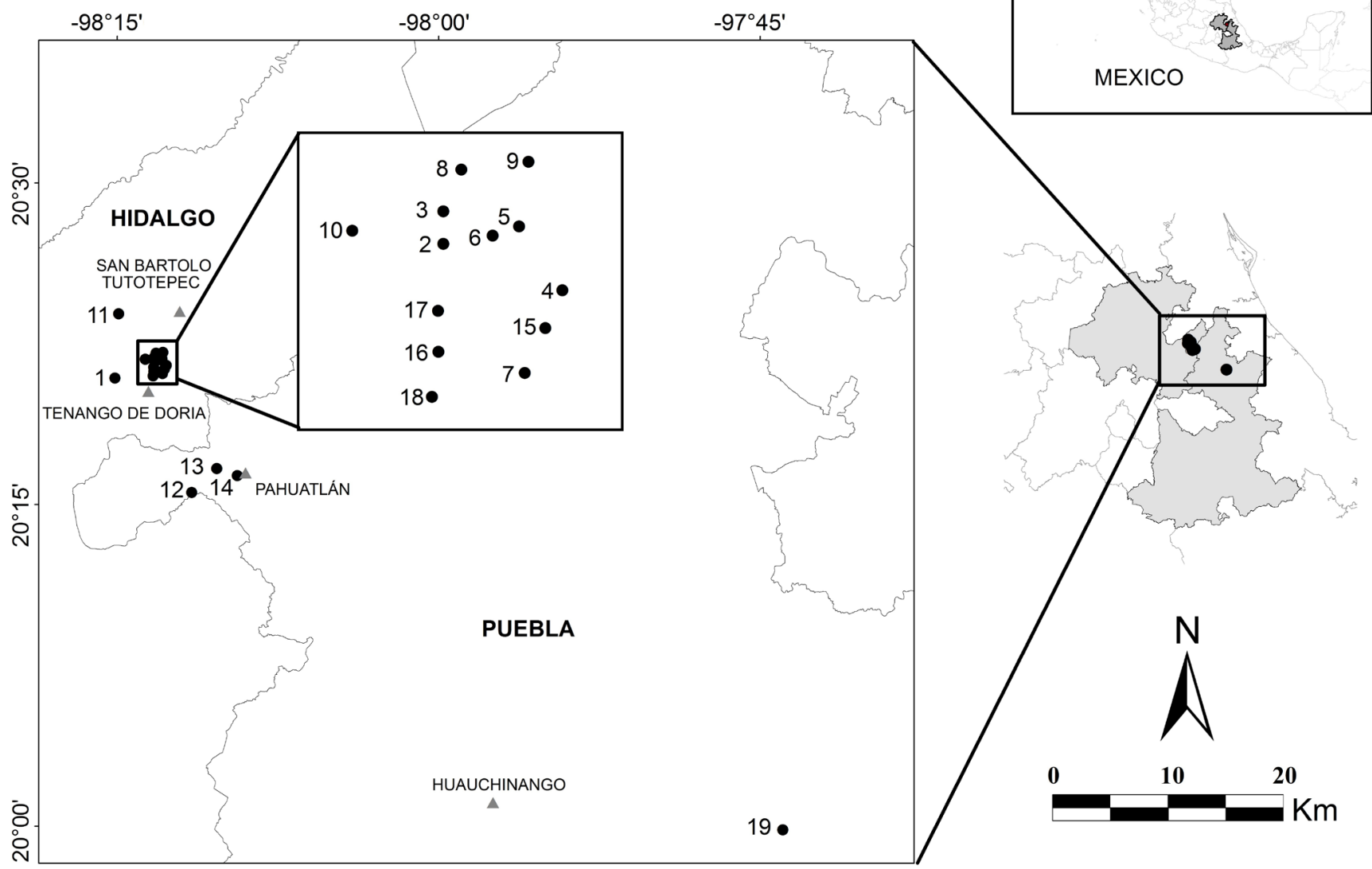

Figure 1 Outcrops localization: 1) La Fiesta; 2) Bopo 1; 3) Bopo 2; 4) Bopo Centro; 5) Bopo 3; 6) Bopo 4; 7) Bopo 5; 8) Temapá; 9) Temascalapa; 10) Ten-Río/Las Juntas; 11) Peña Blanca; 12) Honey; 13) Potrero; 14) Chipotla; 15) Tv 4; 16) Ten 1; 17) Ten 3; 18) Ten 7; 19) Zongozotla. 
the town of Tenango de Doria, represented by four different lithofacies. They considered the Huayacocotla Formation as a group, containing Despí, Las Juntas, Temascalapa, and Tenango formations. Blau et al. (2001) described a new genus and two new ammonite species, by which they discussed the marine proto-Atlantic-Pacific connection through the Mexican territory during the Jurassic. The Huayacocotla Formation rocks are described (Erben, 1956) as a sequence of marine sandstone, siltstone, and shale with interbedded sandy limestone. They are outcropped in the north of Veracruz State, lying to the northeast of Hidalgo State and north of Puebla State.

On the other hand, Dueñas-García et al. (1992) complemented the description of the Huayacocotla Formation mentioning an alternating sequence of shale, lightly slaty and orthogonally fractured, along with fine-grained sandstones in thick beds.

In the twenty-first century, important biostratigraphic research was carried out by Blau and Meister (2000), Blau et al. (2000, 2001, 2003, 2008), and Meister et al. (2002, 2005), who described more ammonite species from the Tenango de Doria area. In addition, the geochemistry research (Angeles-Cruz, 2006; Flores-Castro et al., 2006), suggested the Huayacocotla Fm. to be a single unit by its origin, regardless of the four lithological units proposed by Schmidt-Effing (1980).

As a result, the knowledge of this formation is more advanced than what is revealed in international literature. An example is Westermann (2004) who compiled information about the Jurassic in the circum-pacific region, but scarcely mentioned the Early Jurassic of eastern Mexico. However, based on the classification of kingdoms and domains of the Mesozoic faunas, Westermann (1996, 2000b) explained that this unit was deposited in a paleobasin related to the Western Paleotethys.

The first paleoenvironmental studies began with Esquivel-Macías (2003), Esquivel-Macías et al. (2005, 2007), Gayosso-Morales (2007), Granados-León (2007), Hernández-Velázquez (2007), Arenas-Islas et al. (2009), and Esquivel-Macías et al. (2014). In these papers, only the sedimentary and biotic components are considered.

One reason to study the Huayacocotla anticlinorium is the relative scarcity of Lower Jurassic rocks in Mexico. The geological studies of these rocks have been conducted by Erben (1956), Carrillo-Bravo (1965), Aguayo-Camargo (1977), Pedrazzini and Basañez-Loyola (1978), Schmidt-Effing (1980), Suter (1980), Mendoza-Rosales et al. (1992), Rueda-Gaxiola et al. (1993), Ochoa-Camarillo (1997a, 1997b), and Arellano-Gil et al. (1998), while the paleontological papers include: Díaz-Lozano (1916), Cantú-Chapa (1971, 1998), Silva-Pineda (1978), and Ochoa-Camarillo et al. (1997b).

On this last issue, there are other paleontological studies (Aberhan, 1994; Aberhan and Muster, 1997; Aberhan, 1998; Damborenea, 2000) with pertinent evidence of the passage of several taxa through such connections between the Pacific and the proto-Atlantic. The importance of the Liassic (sensu Bloos and Page, 2002) units also involve the presence of adjacent Middle Jurassic sequences related to the origin of the Gulf of Mexico and its associated fossils

\subsection{LITHOSTRATIGRAPHY AND REGIONAL GEOLOGY}

The lithology of most outcrops in the study area consists of an alternation of fine-sandstone/sandy-siltstone. This agrees with the description by Imlay et al. (1948): several thousand meters of thickness with this lithology, although sediment layers of both lithologies are in the order of millimeters thick. It is also consistent with the descriptions by Schmidt-Effing (1980) and Schlatter and Schmidt-Effing (1984), of marine Sinemurian beds of terrigenous continental origin, which include layers with fossil plants.

Formations from the interval between Early Jurassic to the Early Cenozoic are outcropping in this region, and their geologic contacts can be observed in SGM 1: 50000 (2004). According to the description of the standard locality (López-Ramos, 1979), the Huayacocotla Formation underlies the Cahuasas Formation (Middle Jurassic) and overlies the Huizachal Formation (Triassic), although this Mesozoic sequence is possibly covered elsewhere. 
At the type locality, the Huayacocotla Fm. is followed by the Middle Jurassic formations: Cahuasas and Tepexic (Figure 2 and 3).

\subsection{PALEOENVIRONMENT AND BASIN EVOLUTION}

\subsubsection{SEQUENCE STRATIGRAPHY}

There are no studies in terms of sequences stratigraphy, but apparently the main sedimentary cycles, unlike the Huayacocotla Fm., are represented by different Jurassic regional formations. These represent a large part of the Jurassic and mark a general trend of depth increments, starting with an obliterated basin by the integration of the Pangaea during the Permian, passing through progressive stages of opening of an epicontinental basin communicated to the paleo-Pacific, and eventually through the opening of the Gulf of Mexico (Cantú-Chapa, 1998; Sedlock et al., 1993) and the subsequent expansion of the Central Atlantic.

These phases are documented through the different formations in the area, perhaps highlighting that the Huayacocotla Fm. represents the initial

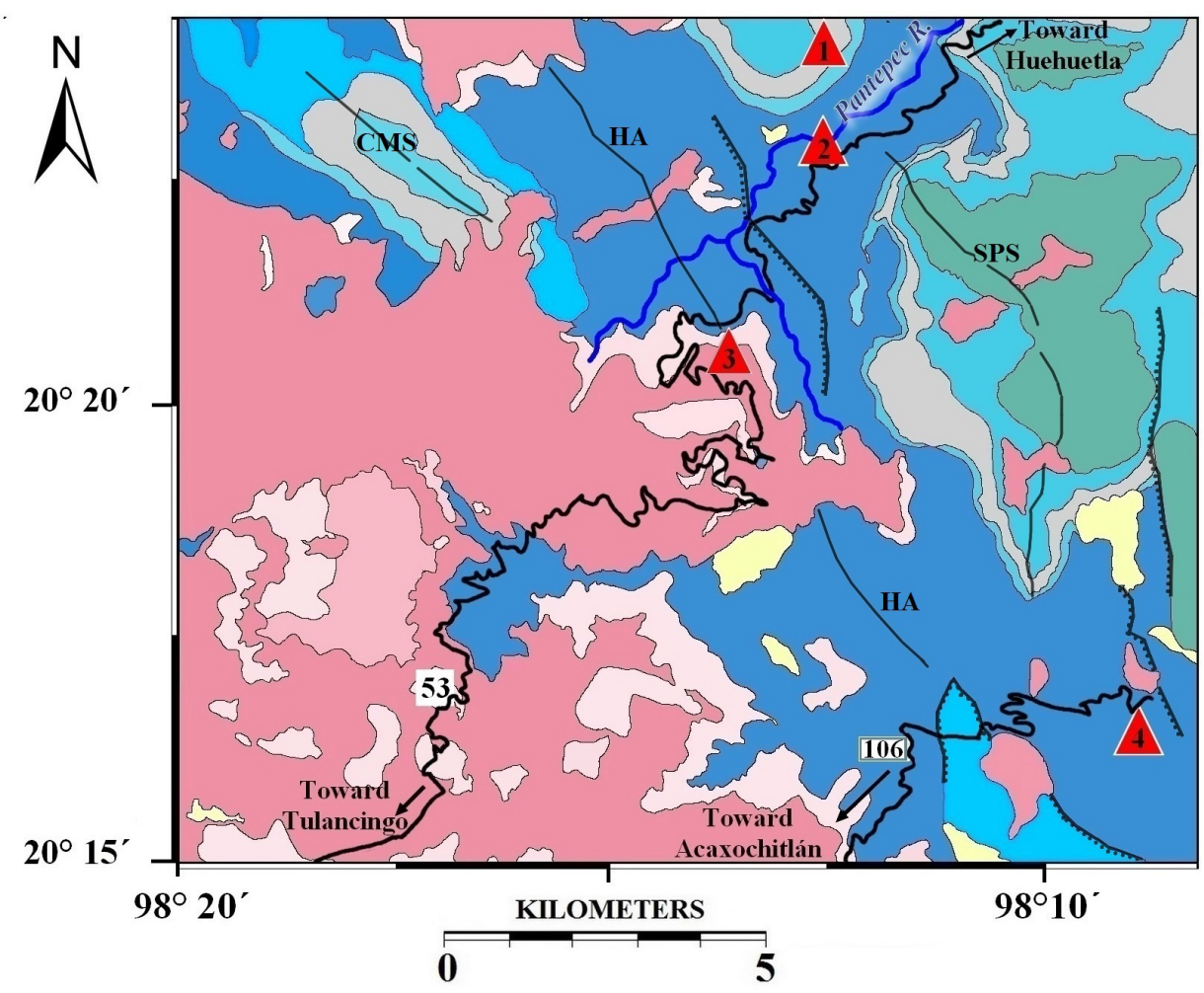

QUATERNARY

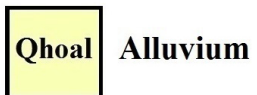

TERTIARY

NEOGENE

TpIPc Pyroclastic

\begin{tabular}{|c|c|}
\hline TpI \\
Da-R
\end{tabular} Dacite - Rhyolite

\begin{tabular}{|l|l|}
\hline TpI \\
B-A
\end{tabular} Basalt - Andesite

\section{CRETACEOUS \\ LOWER}

\begin{tabular}{l|l} 
Kbece \\
Cz- Lu
\end{tabular} Limestone - Shale

JURASSIC

UPPER

\begin{tabular}{|c|c|}
\hline $\begin{array}{c}\text { Jpo } \\
\text { Kbe } \\
\text { Cz- Lu }\end{array}$ & Limestone - Shale \\
\hline
\end{tabular}

\begin{tabular}{|c|c|}
\hline $\mathrm{Jk}$ \\
$\mathrm{Cz}-\mathrm{Lu}$
\end{tabular} Shale - Limestone

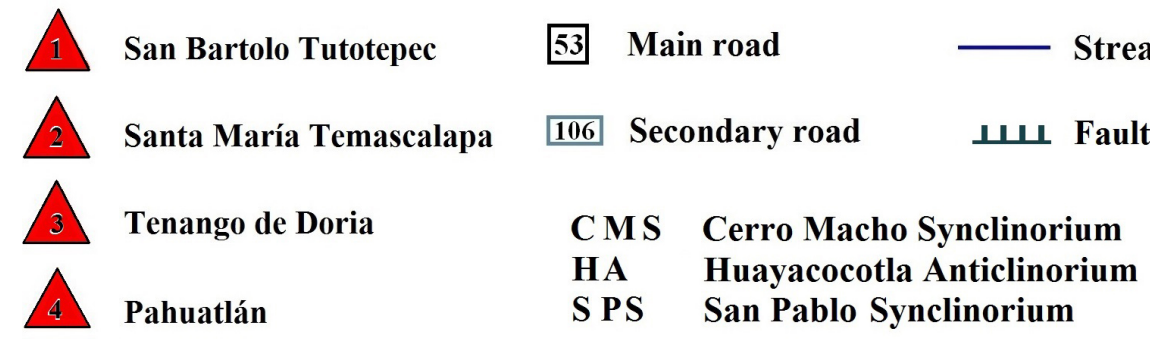

MIDDLE

Jbjb Ar-Lm Sandstone - Siltstone

LOWER

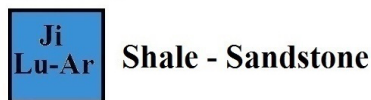

Figure 2 Regional geology 1:50000. Modified from F14-D73 Chart (SGM, 2004), on the basis of the lithological principles of Pettijohn (1975). 


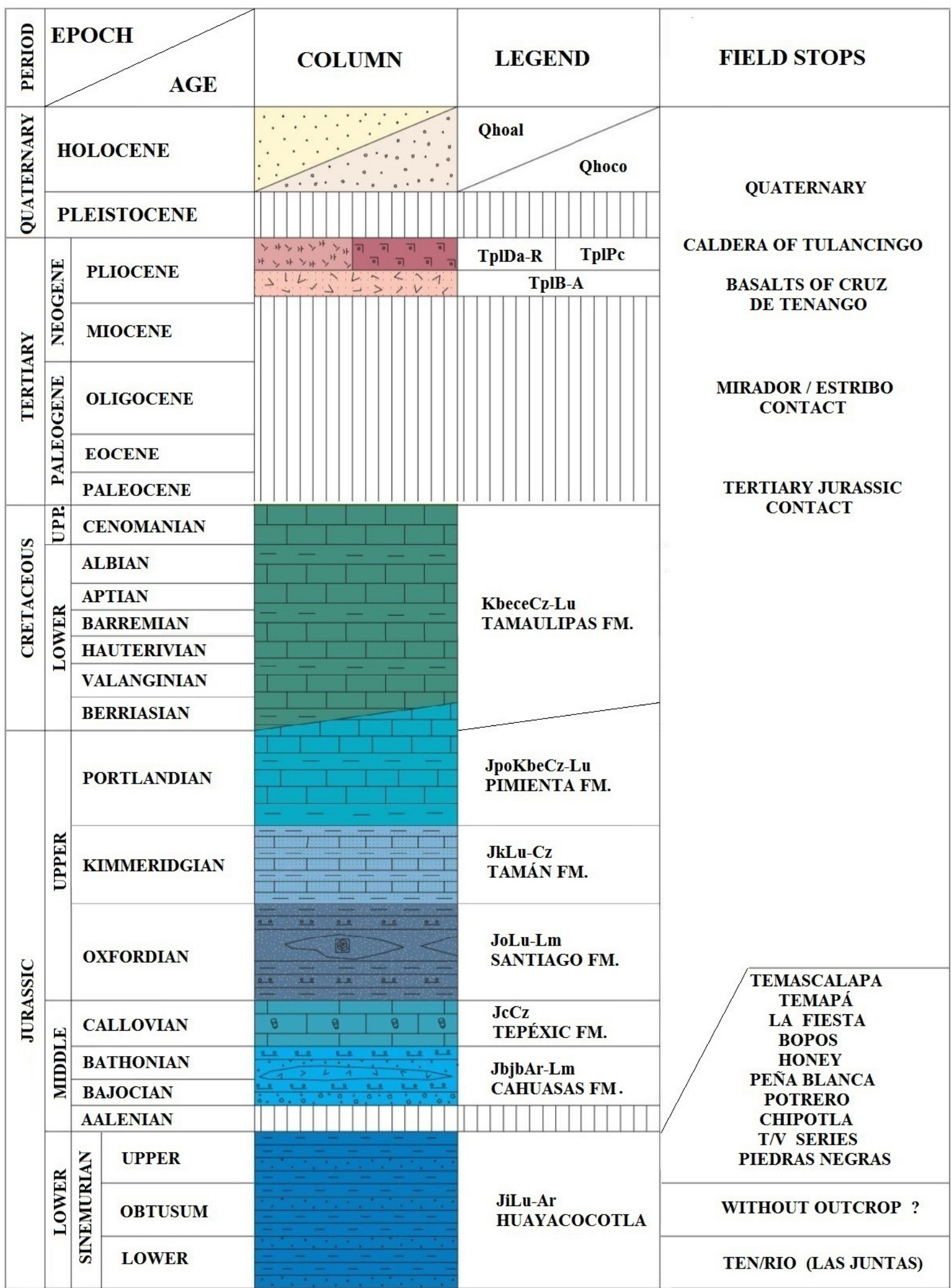

Figure 3 Lithologic column. (UPP. Upper; FM. Formation). Modified from F14-D73 Chart (SGM, 2004), on the basis of the lithological principles of Pettijohn (1975). 
process of communication and faunal exchange (Hispanic paleocorridor hypothesis, sensu Damborenea, 2000) between the Pacific and Tethys western basins (and vice versa) in a back-arc environment, associated with a deep basin in subduction towards the west. This basin was filled by argillaceous sediments containing abundant sedimentary-exhalative minerals (from blacksmokers) that would prove its expansion towards the west; the subduction plane would have triggered the development of the trans-arc basin and therefore the proper arc.

Thus, the Huayacocotla Fm. contacts structurally with the Bajocian Formation in a third-order sequence, then underlies the Bathonian in other contacts that are also due to structural deformations. Their contacts with the Tepexic Fm. (Callovian, Middle Jurassic) are not clear, although widely reported and even mapped roughly, without detailed verification. From then on, the region is structurally complex and allows discordant contacts with many Upper Jurassic units, such as the Santiago Fm. (Oxfordian age), the Tamán Fm. (Kimmeridgian), or the Pimienta Fm. (Portlandian). These inferred contacts do not have field verification. This last relationship would be of the third order.

The Neocomian of the Taraises/Sanctuario Fm. is also present in the area, which would mean a second-order relationship between these sets of sedimentary cycles. On the other hand, at the base of the reviewed Mesozoic sequence, there is an indication of the presence of Triassic beds, but its detailed chronostratigraphy is not known in the Huizachal Fm., which consists of red sandstones of continental origin.

The Huayacocotla Fm. appears as a consistent natural sedimentary unit deposited in a back-arc basin. It is well known that the Huayacocotla Fm. was a part of a regressive context under conditions generated by an erosive, eustatic, and rapid sediment filling. Also, it is observed in the upper discordance with deep basin formations and in the lower discordance with coastal sequences. Therefore, the Huayacocotla Fm. can indicate transgressions and regressions of different orders of magnitude, under a generally deepening trend. It is also compatible with the underlying Triassic sets, situated chronostratigraphically below and possibly in contact with the flysch of the Guacamaya/ Tuzancoa Fm., which represents an ancient phase of the tectonic integration of Mexico as the edge of the Pangea collision.

Within sequences that are not condensed (as this), the parasequences and systems tracts are not obvious, and thus the predominant relative and eustatic sea levels both seem stable (sensu Coe et al., 2003) during the deposition time. These units represent just a brief time, considering that it was a very active tectonic continental separation environment, which produced pulses of sea level changes along the millions of years that the Jurassic lasted.

The stability of such a basin suggests that it represents a few hundred thousand years under an intense siliciclastic sedimentation rate, already indicated by Esquivel-Macías et al. (2005).

\subsubsection{FACIES}

Schlatter and Schmidt-Effing (1984) defined four units: Las Juntas, Temascalapa, Tenango, and Despí. They described the clearly recognizable lithological differences; Tenango and Despí are composed of slate-shales and siltstones respectively. They also recognized Las Juntas for its fossiliferous slate-shale lithofacies. The Temascalapa unit has turbiditic features, evident from a rhythmic alternation of sandstones and shales, with fewer fossils of the same taxa of ammonites than in the other lithofacies. However, the unification of facies with geochemical and fauna content criteria (Angeles-Cruz, 2006) allows the assertion of its recognition as a Formation.

As an example, in the turbiditic Temascalapa facies (Figure 4a) the cyclic uniform accumulation of hemi-pelagic sediments with neritic sandstones from mid-distal environments contain the same fauna as the neritic sandstones of mid-distal upper facies, which obviously conform to a rhythmical lower slope sequence.

This is relevant since both geochemistry and taxonomy demonstrate that Temascalapa is a facies of the Huayacocotla Fm. sequence. With respect 
to the other facies of the area, this facies is the third in terms of coast-ocean gradient, and its sedimentary pulses represent few hundred thousand years. The more uniform distal facies of the Huayacocotla sequence is a consequence of slower accumulation of shales and outcrops at the mouth of the Camarones River, and is named Las Juntas by Schlatter and Schmidt-Effing (1984) (Figure 4b). Both the Despí (Figure 4c) and Tenango facies (Figure 4d) (sensu Schlatter and Schmidt-Effing, 1984) represent deposition in a neritic platform, with evident thin layers as a product of tidal cycles. The set belongs to an intra-arch epicontinental basin, evidenced by both flasser and hummocky sedimentary structures, from a weak tide cycle where one centimeter of sediment represents approxi- mately a year of sedimentation (Esquivel-Macías et al., 2005). Therefore, it is now pertinent to briefly discuss the paleoenvironmental basin analysis with the help of taphofacies and sedimentology evidence.

\subsubsection{TAPHOFACIES AND SEDIMENTOLOGY}

The Huayacocotla paleobasin was a semi-restricted epicontinental sea, with normal to high productivity in physical-chemical parameters in the water column and reduced oxygen conditions at the bottom. These conditions, coupled with a high sedimentation rate, were favorable for the fossilization of nektonic and scarce benthic elements. In such conditions, the minor sedimentological variants or taphofacies characterization assess-
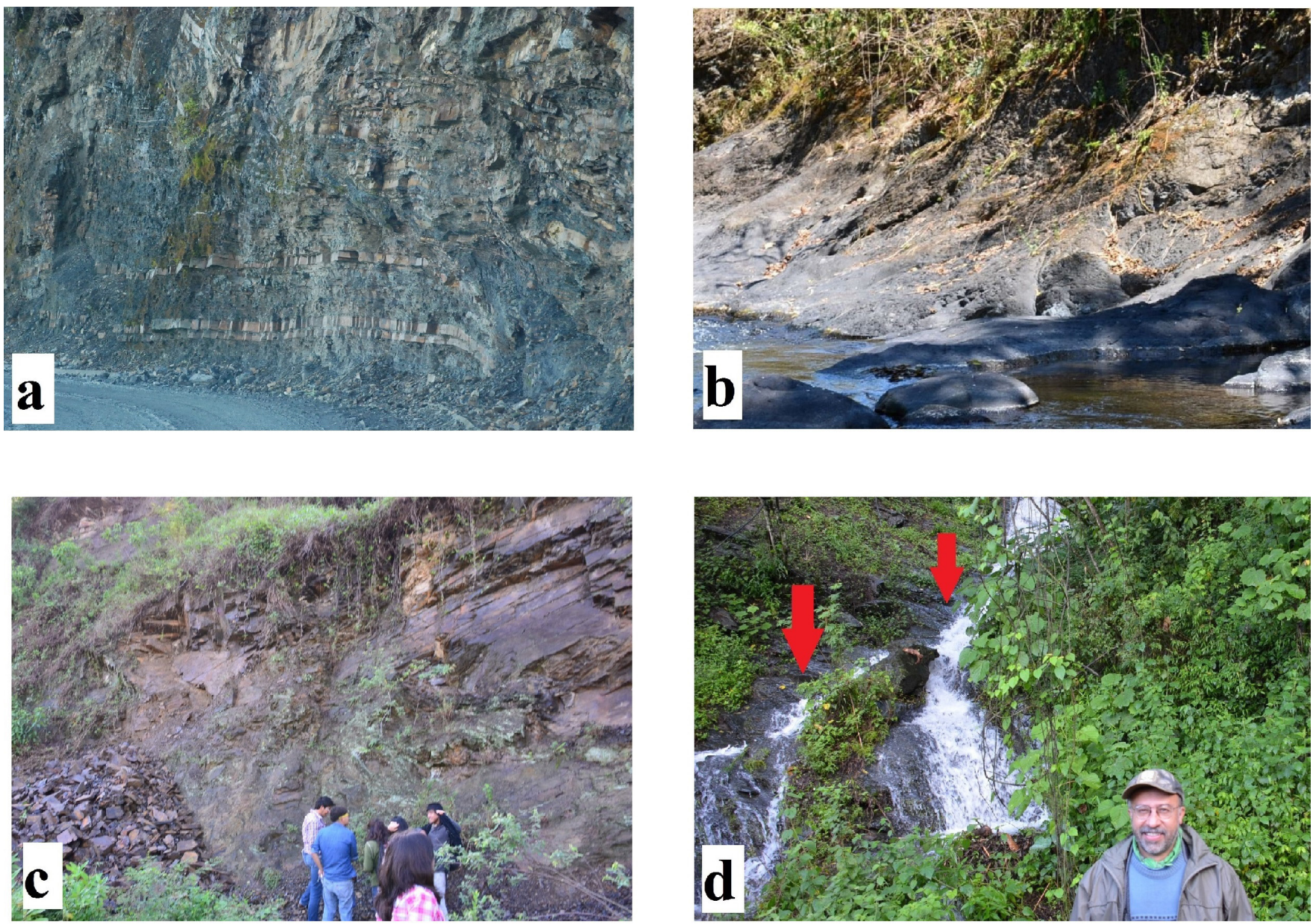

Figure 4 Some different details in the field stops during the trip. a) Temascalapa facies, as can be seen along the route to Temascalapa village; b) Las Junas facies. It can be seen as slaty black siltstoneat Camarones River; c) Despí facies at Temapá outcrop. It is one of the best representatives of such lithology; d) Black siltstone (red arrows) from Tenando facies at Piedras Negras outcrop. 
ments unveil specific sedimentary features, such as: sedimentation rate, environmental energy, tidal regimes, depth, and distance from shore. On the other hand, the characteristics of the water column can be partially deduced by the ammonoids present. The ammonoids and bivalves found were also used to calculate their particular functional-morphology frequencies regarding the environment (habitats spectrum), as well as the diversity and abundance indexes. Thus, it is possible to obtain relevant information for modeling the details of the paleoenvironment. Arenas-Islas (2012) and Esquivel-Macías et al. (2014) allowed the definition of taphofacies associated with its minor variants related to distance, depth, or topography, and correlated them with taphonomic attributes, such as: drilling of shells, epibionts, disarticulation, position, orientation, deformation, fragmentation, preservation, and dissolution. All these attributes were represented in ternary diagrams for visually depicting trends related to attrition and preservation of the remains (Figure 5). In particular, the taphonomic damage pattern of bioclasts generated by the conditions of each taphofacies is evidence of paleoenvironmental dynamics. On this basis, the following taphofacies were recognized:

Taphofacies 1: Implies normal sedimentation in a neritic platform. The lithology may be sandy siltstones or shales with remains of large ammonites that are not in contact with each other.

Taphofacies 2: Involves intermittent high-energy phenomena with remains of ammonoids and bivalves with moderate drag level, which oriented and crowded them even while letting them maintain their taxonomic identity.

Taphofacies 3 to 5: Recognized as the product of temporal fluvial influence that has led to concentrated organic remains with different degrees of attrition and orientation, reflecting their different origin.

Taphofacies 6: Developed in the same lithofacies as 1 and 2; it represents gravitational landslides from the edge of the shelf margin and/or upper parts of the slope, concentrating the fragments of crinoids and ammonites.
The results of the taphonomic analysis are consistent with paleoenvironmental indications provided by geochemical data (Angeles-Cruz, 2006; Flores Castro et al., 2008; Esquivel-Macías et al., 2014), indicating a relationship between the paleobasin and unique sedimentary events, in terms of the contemporary design and evolution of this paleobasin. For example, the virtually identical behavior of the element's concentrations in these geochemical analyses also indicate reduced oxygen conditions (disoxic). The disoxic level and high $\mathrm{pH}$ is common in most of the outcrops. Similarly, the protolith of intermediate igneous composition, produced under an island arc (back-arc basin), and the tectonic regime, both indicate reduced oxygen conditions. The major and trace elements have an identical pattern in all the outcrops, which indicate their common deposition and origin. In addition to these data, there is a positive anomaly in the concentrations of the europium's isotopes found here, confirming the reducing environmental conditions. This anomaly is also consistent with the high value of $\mathrm{pH}$, which favored the dissolution of the shells. By putting together the evidence of the nature and identity of the outcrops, it is favorable to propose a taphonomically consistent model, as the one described in Figure 5.

\subsubsection{FAUNAL AND FLORAL COMPOSITION}

The outcrops to be visited show the occurrence of the species identified and reported by Burckhardt (1930) as well as more than 100 taxa that were later recognized by Erben (1956). In subsequent contributions (Schmidt-Effing, 1977, 1980; Contreras and Núñez, 1984; Schlatter and Schmidt-Effing, 1984; Meister et al., 2002, 2005; Blau et al., 2003, 2008; Esquivel-Macías et al., 2005, 2012; Arenas-Islas et al., 2009), those determinations were refined and some new species were described.

However, at this study area there were no records of other mollusks or echinoderms until Esquivel-Macías et al. (2012) reported the first Sinemurian bivalves, which support the theory of faunistic interchange across the Hispanic Paleo-corridor (Damborenea, 2000). On the other hand, Esquivel-Macías et al. (2005) reported pseudoplanktonic 


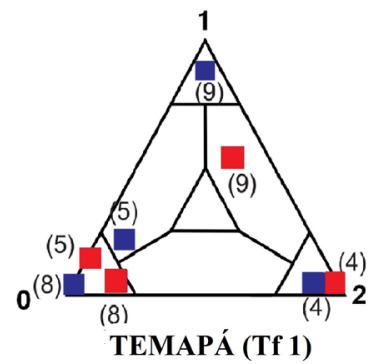

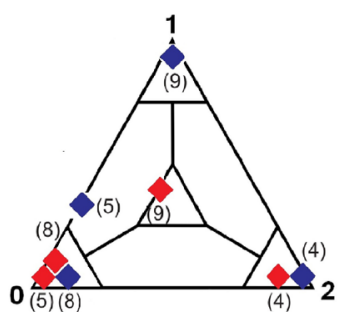

LA FIESTA (Tf 2)

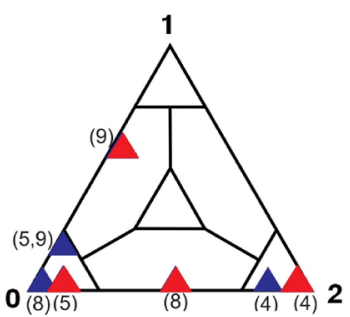

EL POTRERO (Tf 3)

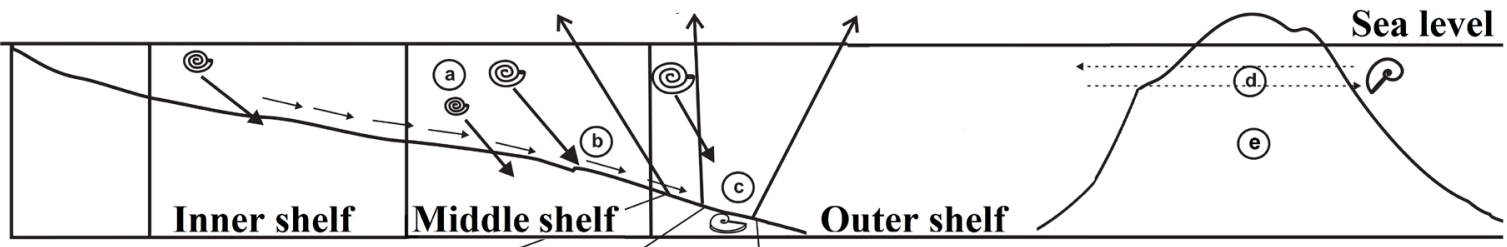

(k)
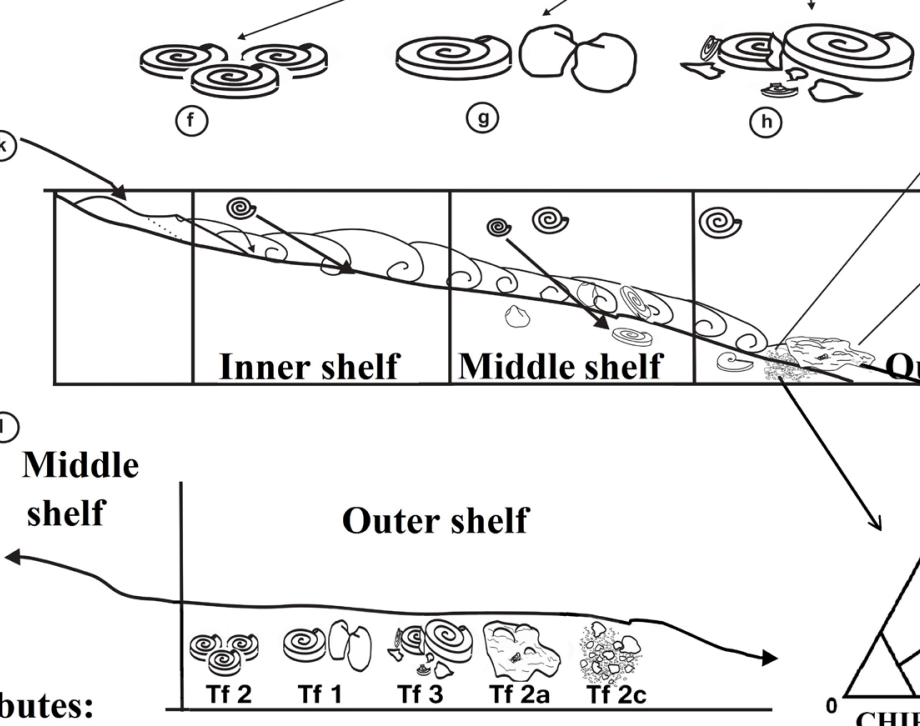

(h)
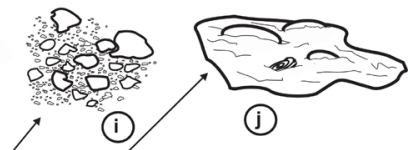

(1)

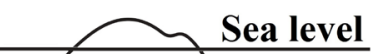

(d.)

(e)

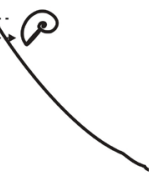

Attributes:

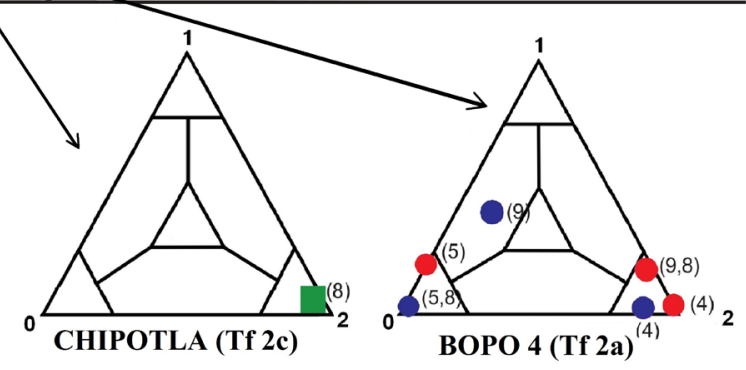

(1) Dissolution

(2) Drilling

(3) Epibionts

(4) Disarticulation

(5) Deformation

(8) Fragmentation

(9) Bioclast size

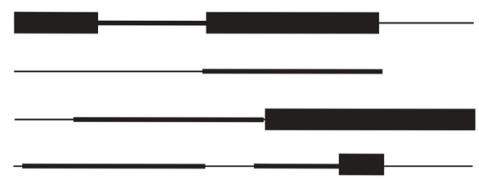

\section{Ammonoids Bivalves Unnamed}

\begin{tabular}{|c|c|c|c|}
\hline $\begin{array}{l}\text { Attribu } \\
\text { (1)-(8) }\end{array}$ & $\begin{array}{c}\text { utes: } \\
\text { No } \\
\text { damage }\end{array}$ & $\begin{array}{c}\text { Low } \\
\text { damage }\end{array}$ & $\begin{array}{c}\text { High } \\
\text { damage }\end{array}$ \\
\hline (9) & 0-6 mm & 6-25 $\mathrm{mm}$ & 26-80 $\mathrm{mn}$ \\
\hline
\end{tabular}

Association 1
Association 2
Association 3
Association 2a
Association 2c

Figure 5 Taphonomic patterns. The environment corresponds to a distal neritic platform: a) The ammonites were organisms whose life developed in the water column; b) Transport of the remains towards the zone of deposit; c) Deposit; d) Presence of Phylloceras as an edge neritic platform inhabitant; e) The existence of an islands arc is proposed on the basis of the geochemical analysis; $f-j$ ) Environs assigned to the taphofacies ( $\mathrm{Tf}$ ) interpreted with ternary taphograms; $\mathrm{k}$ ) Terrigenous deposits due to the possible presence of a river; I) Scheme of the taphofacies gradient with respect to their taphonomic attributes at the deposit place. 
isocrinids as well as microgastropods (Figure 6a) from the Temapá outcrop. The remaining biota from these rocks show vegetable remains originating from firm ground, spores, and various unidentifiable palynomorphs.

Thus, both the flora and fauna are largely dominated by ammonoids, accompanied by some clams and scarce crinoids (Figure 6b), and therefore, the taphonomic evidence of serpulids agree with the paleoecological models published for the Lower Jurassic, as seen below.

\subsubsection{PALEOECOLOGY AND BENTHIC FAUNA}

One of the premises that enable paleoecological conclusions is the morphofunctional analysis, which interprets the organic structures as adaptations. The morphology of mollusk shells is an abundant source of this kind of data (Aberhan, 1994; Landman et al., 1996).

On the other hand, the criterion for the recognition of dragging/depositing in situ for the ammonoids and bivalves is obtained from their taphonomic features (Esquivel-Macías et al., 2005, 2007, 2012, 2014; Arenas-Islas et al., 2009).

In the shaly and sandy siltstones present at most of the outcrops, complete Ortechioceratidae and their relative shells lie down parallel to the bedding surfaces, which are interpreted as in situ deposits. Sometimes there are also abundant clams and other remains. Also, there are often associations dominated by the same ammonoids with some degree of accumulation, representing moderate energy levels and intermittent trawling events. Even these remains can be found much more fragmented, taxonomically unrecognizable, but accompanied by crinoids and faunal elements when they were originated at the subtidal level. Also they are representing stronger energetic events from larger distances, with previous fragmentations due to wave action. In addition, there are also other taphonomic variants which characterize the taphofacies (Esquivel-Macías et al., 2014).

In summary, according to their fossils and their respective taphonomic associations, most Sinemurian outcrops represent a mid-proximal/neritic zone paleoenvironment. This basin was inhabited by organisms with nektonic, benthonic-epifaunal, as well as shallow infaunal habits. The sediments were of an unstable nature with high siliciclastic sedimentation rates.

Regarding the oceanographic conditions, we can infer that the water masses had high primary productivity, according to the amount of nutrients shown (trace and major elements) (Angeles-Cruz, 2006). Therefore, these waters were dominated by filter feeders, as shown by the abundant ammonoids and clams in the samples.

Concerning the nature of the bottom waters, Angeles-Cruz (2006) and Flores-Castro et al. (2008) reported that the fossilization occurred in suboxic
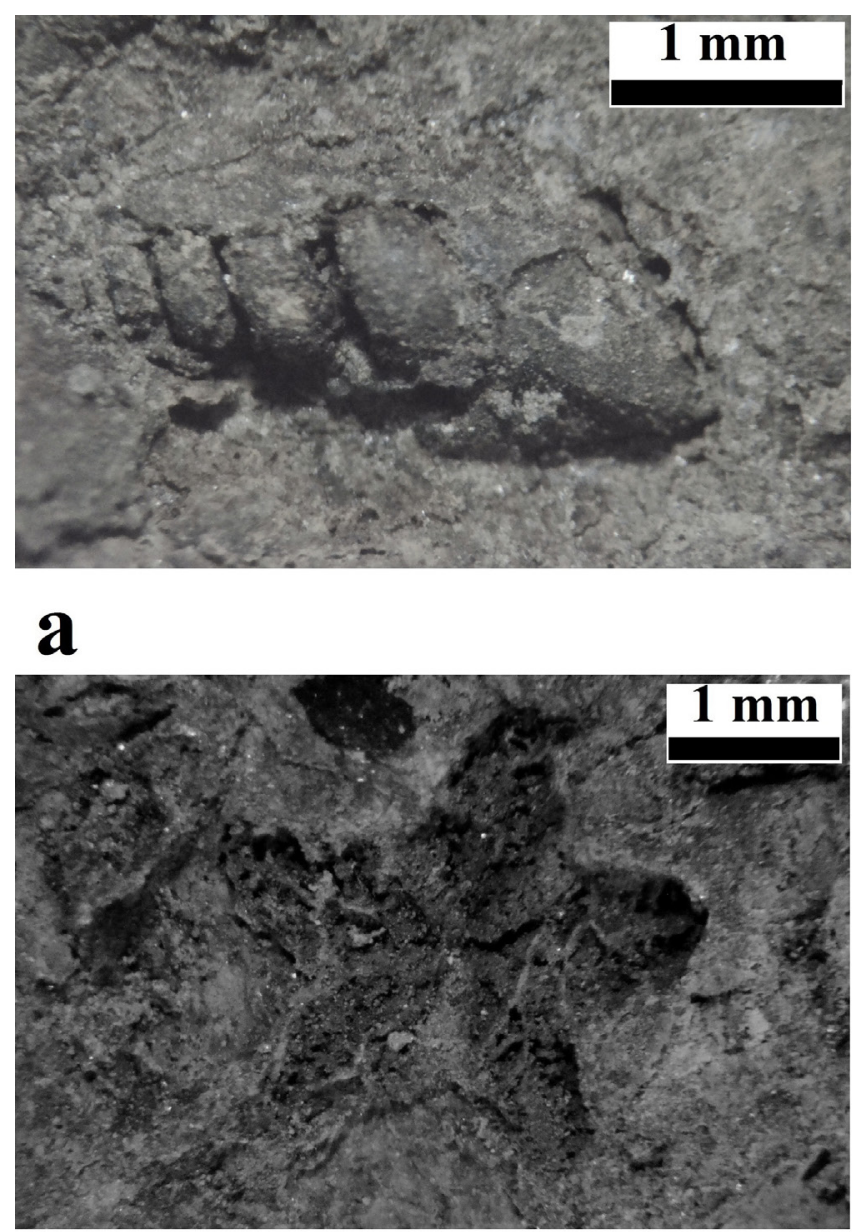

b

Figure 6 Benthic microfauna are very common in the ammonoids assemblages: a) Microgastropod from Despí facies; b) Crinoid from Despí facies. 
to euxinic conditions, even disoxic at some localities. The slate-shales here involve a distal/deeper anoxic facies and low-energy conditions with high pyritization.

Considering the organisms in the Huayacocotla Formation, all the "bambachian" ecological mega guilds (Bambach, 1983) are represented along with the biodiversity of ammonoids and bivalves with paleoenvironmental value, especially the filter-feeders and predators which give the particular structure to this fossil association.

Among these, there are: Nuculana sp. (infaunal passive filtering inhabitant of mobile shallow sediments, with benthic biofilm microphagous habits), Posidonotis semiplicata (epifaunal, byssate, reclined in soft sand with suspensivorous passive habits), Gervillaria sp. and Bakevellia sp. (they tolerated either suboxic distal environment and disoxic coastal environments and had passive suspensivorous habits), Weyla alata (inhabitant of the shallow sandy bottoms with suspensivorous habits in water that had high organic content), Gervillela sp. (epibyssate bivalve with probably suspensivorous habits, found in subtidal neritic proximal hard bottoms), Neocrassina sp. (infaunal and not byssate, found in soft sandy bottoms with a high content of organic matter), Protocardia sp. (infaunal shallow, suspensivorous in oxygenated and slightly unclear water), unidentified crustacean Brachyura? (active carnivorous neritic epifaunal), isocrinids crinoids (pseudoplanktonic organisms attached to floating organic objects carried by rivers), multiple echioceratids (possibly carnivorous or herbivorous) and Phylloceras sp. (active nektonic carnivore). Additionally, there are gastropods (epifaunal active herbivorous) and serpulids (upper infaunal active suspensivorous). All of them appear together when LA FIESTA, TEMAPA, PEÑA BLANCA outcrops are collectively considered.

The Wilson ID was used in the Chipotla outcrop (Figure 1) to demonstrate the diversity with 25 species of ammonoids and bivalves: the calculated total value was 0.87 , with a dominance value of 0.95 induced by the particular abundance of the clam Neocrassina sp.
This outcrop, which is considered representative of the Huayacocotla Fm., was analyzed to determine its size structure (Esquivel-Macías et al., 2012). For instance, in layer 6, there were millimetric fragments in a wavy sandy matrix, and other intervals of centimeter order with complete shells. Here, Gervillela and Neocrassina shells could still be articulated and their sizes were uniform; so the drag was moderate, since they lived on the deposition site representing the sandy matrix in shallow facies. In layer 5 and 7, the size structure was around $12.7 \mathrm{~mm}$, which meant a bioclast selection. All the specimens of Paltechioceras rothpletzi were complete and concordant with bedding planes, indicating moderate drag, but they also suggest postmortem disaggregation, given the consistent absence of $a p$ tychus. The same is indicated by the twenty articulated valves among the forty Neocrassina sp. valves. In layer 3 of this outcrop, the ammonoid shell size is large and very small unselected clams appear; these are interpreted as para-autochthonous.

As layer 6 contained 19 out of the 25 taxa of this outcrop, which represent different environmental requirements, it is interpreted (Esquivel-Macías et al., 2012) as the product of a community more complex than those at layers 5 and 7 , which have only $P$. rothpletzi. On the other hand, layer 6 is enriched with Gleviceras cf. chofatti, Paltechioceras hardbledownense, P. rothpletzi, Weyla sp., Nuculana sp., Protocardia sp., Neocrassina sp., Gervillela sp., and Brachyura?, all of which are representatives of a shallow facies.

Considering that the fauna was retained at the disoxic and euxinic bottoms, the interpretations for the Jurassic communities type 65 "silty clay" and 66 "muddy sand" (McKerrow, 1978) are compared as follows:

Silty Clay Community from Early Jurassic shows Eoderoceras as demersal/epibenthonic functional ammonite, crinoids, serpulids, and pectinids, building a faunal structure very similar to those described here in terms of bambachian guilds, although the rest of the dominant fauna in the Huayacocotla Fm. are nektonic ammonoids (McKerrow, 1978). Muddy Sand Community had functional epibenthic 
and nektonic cephalopods, isocrinids, pectinids, and serpulids, but in Huayacocotla Fm., the main product of taphonomic accumulation is a great diversity of ammonoids.

The particular faunal mix comes from the well oxygenated neritic platform along with many nektonic elements explaining the high para-autochthony; also, the random arrangement of bioclasts with articulated clams suggests that the burial occurred over still living benthic associations mixed with the dead nektonic shells deposited from the water column. The shell collapse limit for Phylloceras was calculated to be $482 \mathrm{~m}$, which indicates that an empty shell found collapsed was deposited deeper than $482 \mathrm{~m}$ (Westermann, 1996). All this suggests environmental conditions that require the presence of rivers, producing the accumulation of sediments that slip gravitationally after their accumulation from neritic platforms to disoxic bottoms. This explains the presence of several facies in the final sediment as in layer 6 of the Chipotla outcrop.

According to Landman et al. (1996), the Jurassic hypoxic epicontinental basins have been thoroughly studied and are defined by their oxygenation level, based on chemical and biotic conditions of marine sediments. Thus, in disaerobic basins (Oxygen circa $[0.3$ and $1.0 \mathrm{ml} / \mathrm{l}])$, the benthic fauna is restricted to some rhynchonellid brachiopods and some bivalves, such as Posidonotis and Bositra (Aberhan and Pálfy, 1996). There are also suboxic basins with even lower concentrations of oxygen or completely anoxic (euxinic) environments with high concentrations of sulphides derived from organic matter concentration, anaerobic bacterial activity, and even exhalative hydrothermal influence. These sediments produce dark gray to black shales, and may contain pyritized and calcopyritized fossils.

\subsection{BIOSTRATIGRAPHYANDGHRONOSTRATIGRAPHY}

The Huayacocotla Fm. covers an age range from the Early to the Late Sinemurian (Figure 3). This is a relatively short geological interval considering that deposition occurred in a framework of environmental stability. This condition produced a non-condensed sequence ("developed" in the sense of Craig et al., 1993) with high sedimentation rate. Therefore, the faunal changes were more rapid than the geological ones, as indicated by the reported changes in the biozones. However, by contrasting the faunal lists with chronostratigraphic ranges based on European zonation, a persistent absence of taxonomic elements from the Obtusum zone is revealed, a pattern that apparently contradicts the quality of the "developed" sequence of the Huayacocotla Fm. Furthermore, the data show this pattern through biostratigraphical descriptions of 17 outcrops produced by many different researchs which support the Obtusum gap. The seemingly contradictory presence of Lower Sinemurian taxonomic elements listed in the following outcrops descriptions are in obvious reference to the upper and top uppermost Sinemurian. This pattern will be named "interrupted pattern" (Figure 7).

Such an assessment is consistent with the recurrent presence of the Oxynotum and Raricostatum zones throughout the region, which are evident in each of the outcrops considered by the presence of ammonoid faunas (Contreras and Núñez, 1984; Meister et al., 2002, 2005; Blau et al., 2003, 2008; Esquivel-Macías et al., 2005, 2012, 2014; Hernández-Velázquez，2007; Gayosso-Morales, 2007; Granados-León, 2007; Arenas-Islas et al., 2009). The geochemical data (Angeles-Cruz, 2006; Flores-Castro et al., 2006, 2008; Angeles-Cruz et al., 2007) also show a uniform protolith compositional profile. All these convergences of arguments suggest that the lithological variations observed were interpreted as mere lithofacies and taphofacies within the same paleobasin, despite the proposal that they were different formations (Schmidt-Effing, 1980; Schlatter and Schmidt-Effing, 1984). 


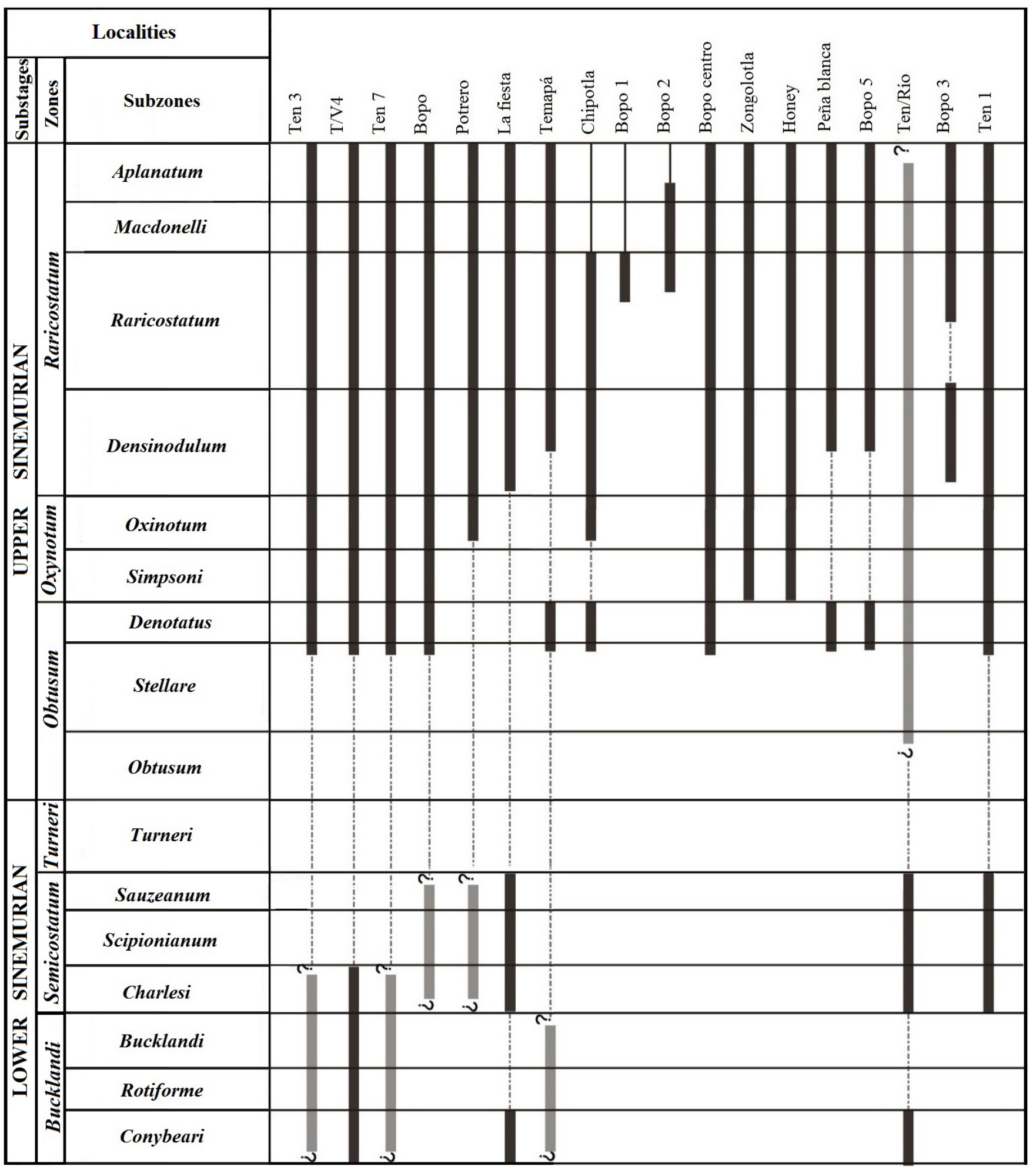




\section{Field stops}

The localities to be visited may vary according to the local situation, since the use of some of these outcrops for quarrying is common in the region. Also, landslides blocking the way to these outcrops may occasionally occur.

It is recommended to avoid collecting material. However, the survey leader will give indications when some material for personal purposes may be collected. Sampling for academic collaboration purposes will be properly treated. Therefore, the use of hammers and cameras will be possible, but not GPS technology or geological and metric scales. The survey leader has the right to request any material considered important for research.

\subsection{DAY 1}

\subsubsection{STOP 1 CALDERA OF TULANCINGO}

Tulancingo valley is located inside a volcanic caldera, which is surrounded by remarkable igneous structures (Figure 3). To the northwest, the Navajas Range, which is a set of dacitic ashes and consolidated tuffs with obsidian remains, is easily seen in various sites along the Pachuca - Tulancingo Federal roads. On the main road across Tulancingo, there is a quarry under industrial exploitation where large volumes of pumice stones are extracted. The section of this quarry shows pulses of massive extrusion of these materials. To the west and southwest of the city lies the dacitic domes (Figure 8a), the last remains of the post-explosive activity of the Caldera of Tulancingo, which produce a series of sharp curves at the highway.

\subsubsection{STOP 2 LA CRUZ DE TENANGO}

After Metepec, the pleistocene alluvial debris is left behind. To the East there is a set of cineritic cones that ejected red pumice ("Tezontle"). The road proceeds with a series of curves up the slope on an Upper Tertiary consolidated tuff and basaltic spill, already very eroded and covered by pine-oak forest, tentatively mapped as the Pachu- ca volcanic group. Poorly kaolinized ashes can be recognized in some places. After the dense woodland summits, the descent into the deep Tenango de Doria canyons begins, with notable changes in the vegetation. The transition towards the basaltic "traps" and consolidated tuffs in the "El Mirador" area can be seen.

\subsubsection{STOP 3 EL MIRADOR / ESTRIBO}

There are two angles of view from Stop 3, situated right on the border between Hidalgo and Puebla states (Figure 8b). To the left (northwest) of the bottom of Tenango de Doria gorge lies the homonymous village. The view from here includes the San Bartolo Tutotepec village and the Pantepec River. On sunny days, a magnificent view of the relationship between Lower, Middle and Upper Jurassic units can be seen, as shown in the Pahuatlán geologic map F14 D73 (1:50000 scale) (SGM, 2004). From this angle, one can observe the contact of the Tertiary volcanics with the small Lower Jurassic hills and the folded Upper Jurassic calcareous rocks of the Pimienta Fm., which lie on the Lower Jurassic silty sands and Middle Jurassic shales. Tenango was built on Jurassic hills, near the Tertiary-Jurassic boundary. To the West, in the high terrains of the village, there are eroded tuffaceous sands ("ash fall" type) originated by the Caldera of Tulancingo activity, forming the ridges between Puebla and Hidalgo states. In the "Estribo," to the right of the deep gorge, the Pahuatlán Valley can be seen, which contains additional Huayacocotla Fm. outcrops to visit.

\subsubsection{STOP 4 TERTIARY/JURASSIC CONTACT}

On the road, just after Tenango village, with its original colonial layout and its eighteenth-century church, the inverse view from the Mirador/Estribo is seen. The Jurassic-Tertiary contact is clear towards the southwest between the basaltic traps and Lower Jurassic looms. The climate and vegetation have changed dramatically. Local stores sell typical fabrics and very fertile agricultural soil has been derived from the erosion of the Jurassic siltstones. 


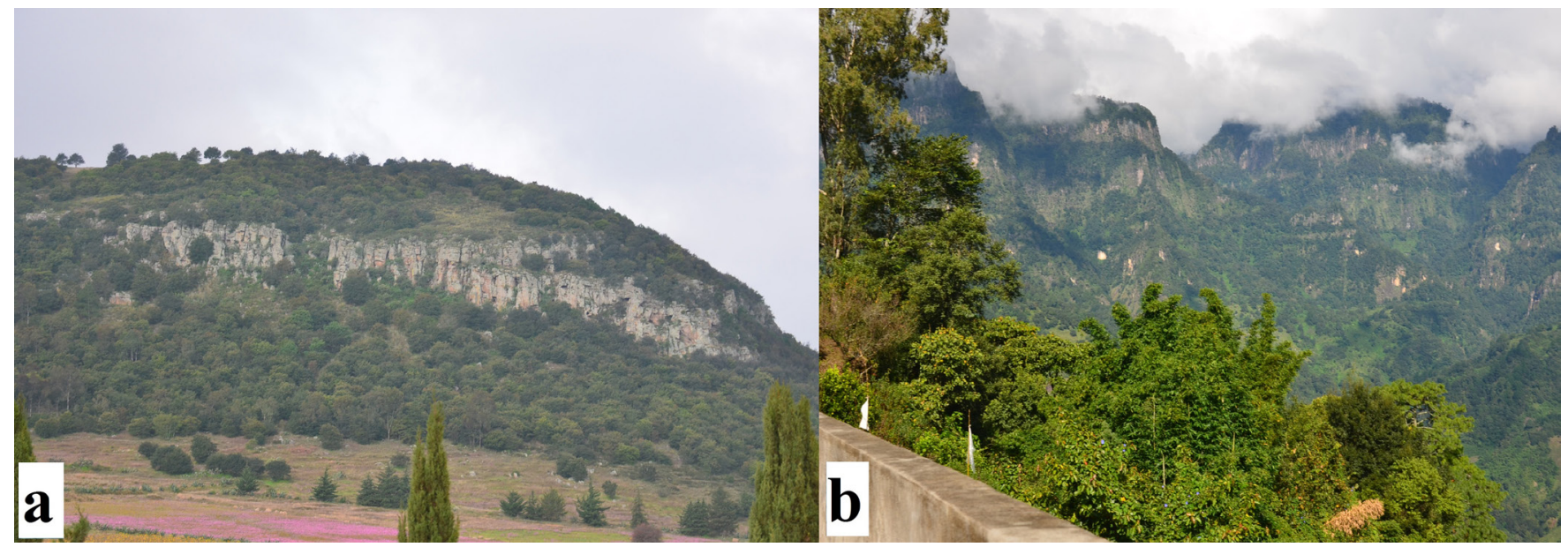

Figure 8 Two geological structures exhibiting the stratigraphic relations expressed in the regional column: a) Dacitic domes; b) Jurassic/Pleistocene contact.

\subsubsection{STOP 5 LA FIESTA $\left(20^{\circ} 20^{\prime} 54.3^{9}{ }^{\prime} \mathrm{N}\right.$; 98 $\left.{ }^{\circ} 15^{\prime} 05.9^{\prime \prime} \mathrm{W}\right)$}

LA FIESTA outcropis located $3.5 \mathrm{~km}$ from the Tenango de Doria village, Hidalgo, on the access road to El Desdaví community. The rocks at this outcrop were used as quarry material despite their paleontological value, and the outcrop is on a hillside with tropical semi-deciduous forests significantly altered by logging. The outcrop presents a 30-meter-thick section with millimetric laminated stratification of very fine sandstones in a silty matrix (Arenas-Islas et al., 2009) (Figure 9).

This outcrop from the Late Sinemurian age, as proved by the presence of: Paltechioceras tardecrescens (Hauer, 1856), P. rothpletzi (Böse, 1898), P. harbledownense (Crickmay, 1929-1930), Paltechioceras gr. burckhardti (Erben, 1956), Ortechioceras jamesdanae (Trueman and Williams, 1925), Ortechioceras cf. incaguasiense (Hillebrandt, 2002), Ortechioceras pauper (Erben, 1956), Plesechioceras cihuacoatlae (Erben, 1956). Many species, already reported in this region by Erben (1956), indicate an age range within the Raricostatum zone, aplanatum to densinodulum subzones, and probably centered in raricostatum subzone (Meister et al., 2005, figure 3) within the favrei and licence/rothpletzi horizons. However, Arnioceras ceratitoides (sensu Hillebrandt, 1981) and Metophioceras sp. (Spath, 1923) [Ammonites coneybeary Sowerby, 1816] are also reported, but they are in-

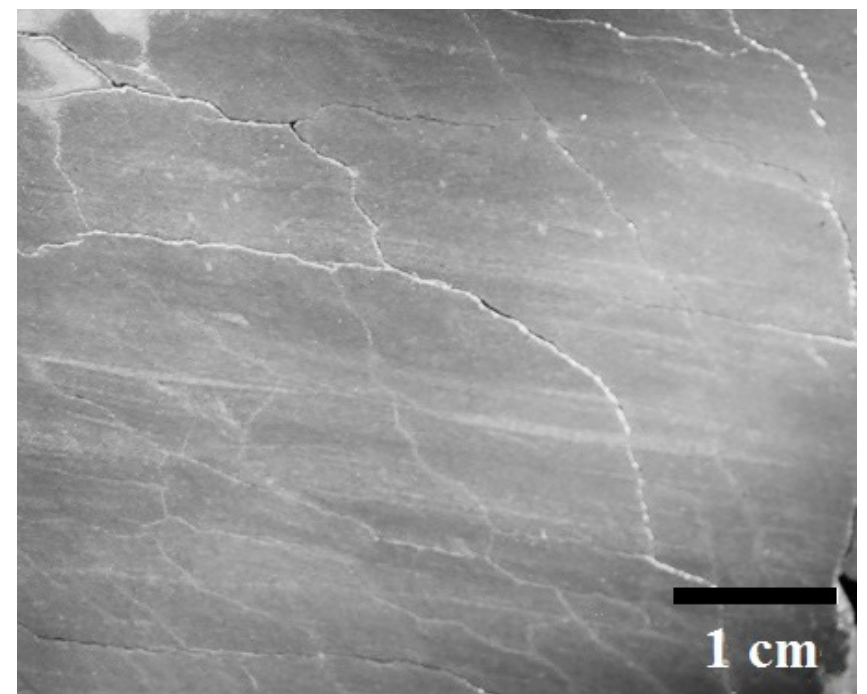

Figure 9 Some characteristic sedimentary structures on sandy siltstones from Huayacocotla.

consistent since they were often referred to belong to the Hettangian and Lower Sinemurian (Meister et al., 2005) (Figure 7).

\subsubsection{STOP 6 PIEDRAS NEGRAS}

Although this shaly outcrop is considered to be Sinemurian in age because of its transitional (facial) contact with the fossiliferous siltstones of the Huayacocotla Fm., it has not produced fossils. Topographically, but not necessarily biostratigraphically, it is above TEN-RÍO/LAS JUNTAS, so it might correspond to the Middle Sinemurian 
(MS), located between the several Upper Sinemurian (US) outcrops at LA FIESTA and Lower Sinemurian (LS) outcrops atTEN-RÍO/LASJUNTAS. These rocks are cut by the Despí creek, a few meters before Piedras Negras village (Figure 4d).

\subsubsection{STOP 7 EL BOPO OUTCROP SERIES}

The Bopo outcrop series occurs along the slope of a normal tectonic block that was produced by the Huayacocotla anticlinorium. This section is under an intense erosion process which does not facilitate access to the fossil material, although there are several outcrops nearby which can be visited; Bopo 3 and 4 are regarded as the most interesting. The route to the Bopo is shown by Schmidt-Effing (1980), and Schlatter and Schimdt-Effing (1984), with the TV/s-series outcrops.

BOPO 1 (20²1'43.3'” N; 98¹3'15.9' W). BOPO 1 is a seemingly exhausted outcrop. It was originally called TEN 2 (Schlatter and Schmidt-Effing, 1984). There is only Phylloceras sp. surviving from the old collection (Meister et al., 2005) and paleotaxodontid clams. Based on such evidence, it was referred to belong to the Late Sinemurian, possibly top of the Obtusum. This is consistent with the rest of the outcrops of the BOPO series, given its current lower topographic position compared to the rest of the BOPO series, which could also be chronostratigraphically correct (Figure 7). The site has a 10-meter front and similar height of sandy siltstone, approximately uniform.

BOPO $2\left(2^{\circ} 21^{\prime} 52.4^{\prime \prime}\right.$ N; $\left.98^{\circ} 13^{\prime} 15.9^{\prime \prime} \mathrm{W}\right)$. This outcrop was identified by Meister et al. (2005, figure 1c) with the number 2. According to Gayosso-Morales (2007), the outcrop is 3-meter wide and 1-meter high. The reported fauna includes: Paltechioceras aff. mexicanum (Erben, 1956) and P. hardbledownense (Crickmay, 1929-1930). It is referred to the top of the Raricostatum zone, raricostatum subzone and favrei horizon, consistent with the upper part of BOPO 3 (Figure 7).

BOPO Gentro (20²1'30.3"; N 98 $\left.{ }^{\circ} 12^{\prime} 42.6^{\prime \prime} \mathrm{W}\right)$. This outcrop is Late Sinemurian, belonging to the Raricostatum zone (Meister et al., 2005), as indicated by the presence of: A. floresi (Erben, 1956), Gleviceras sp. (Buckman, 1913-1919), and P. tardecrecens (Hauer, 1856), which come from more recent collections in the region by the former authors. The chronostratigraphic interval is the uppermost Sinemurian of the region, focusing exclusively on aplanatum subzone, from aureolum/tardecrecens/oosteri/recticostatum horizons (Figure 7). It has a thickness of two meters.

BOPO 3 (20²1'48.2' N; 98¹2'54.7' W). This outcrop seems to have better stratigraphic resolution as compared to the previous ones. It is Upper Sinemurian, proven by the presence of: $P$. aff. mexicaum (Erben, 1956) (Figure 10a), P. hardbledownense, P. burckhardti, Gleviceras sp., (Buckman, 1918), Oxynoticeras aff. soemani (Dumortier, 1867), and O. jamesdanae. Most of these were previously reported in the region by Erben (1956). According to Meister et al. (2005), this assemblage provides for a location in the range of the Raricostatum zone, densinodulum subzone and lymense to echioceras horizons, with the following taxa: $O$. aff. soemani (Dumortier, 1867) and $O$. jamesdanae (Figure 10b). The fauna also extends its range to the Raricostatum zone, raricostatum subzone, focused on raricostatum/crassicostatum to bohemi /cf. intermedium horizons, which have been interpreted as belonging to an upper part and a lower part of the outcrop (Figure 11a). However, Gayosso-Morales (2007) reports the presence of $P$. aff. mexicanum and $P$. hardbledownense which indicate the Raricostatum zone, within the raricostatum, macdonelli and aplanatum subzones, from raricostatum / crassicostatum to the aureolum horizons (Figure 7).

This implies two possibilities: (1) there are three parts in the outcrop (low, middle and upper), or (2) the top part is much more extensive than postulated by Meister et al. (2005). Accordingly, the last criterion is adopted because there are gaps between the middle part and the new top. Possibly, the 2005 sampling was insufficient. The upper part corresponds with BOPO 4 and the TEN 1, TEN 3, TEN 7, T/V 4 (called by Meister et al., 2002); meanwhile, the lower part corresponds, at 
least partially, with T/V 4, T/V 5, T/V 6, TEN 1, TEN 3, and TEN 7.

BOPO 4 (20²1'45.6” N; 98 ${ }^{\circ} 13^{\prime} 02.1^{\prime \prime}$ W). BOPO 4 belongs to Late Sinemurian, divided into two blocks due to an echelon fault above the Bopo 4 block "a". This block has: P. tardecrecens, $O$. jamesdanae, O. aff. soemani (Dumortier, 1867), P. aff. mexicanum, $O$. pauper, and $P$. burckhardti. This set indicates a Late Sinemurian age, precisely in Raricostatum zone, upper raricostatum subzone, macdonelli, aplanatum horizons (Meister et al., 2005; Gayosso-Morales, 2007) (Figure 7). Meanwhile, the part of BOPO 4 block "b" with P. hardbledownense (Figure 10c), Angulaticeras sp., Partsicheras sp., A. ceratitoides (Quenstaedt) sensu Prinz (1895), and Phylloceras sp. is assignable to the Obtusum zone and the denotatus subzone, as reported by Meister et al. (2005).

BOPO 5 (20²1'25.9” N; 98¹2'53.1' W). This outcrop is located quite close to T/V 6 and T/V 5 , thus it is described under the same criteria and data, based on the presence of $P$. tardecrecens, $P$. aff. mexicanum, O. jamesdanae, O. pauper, O. cf. incaguasiense (Hillebrandt, 2002), and Proclivioceras aff. proclive (Rosenberg, 1909). These indicate the place should be in the Raricostatum zone without any doubt, including the densinodulum, raricostatum and aplanatum subzones (Blau et al., 2003; Meister et al., 2005; Gayosso-Morales, 2007) (Figure 7).

\subsubsection{STOP 8 TEMAPÁ $\left(20^{\circ} 22^{\prime} 04.1^{\prime}{ }^{\prime} N\right.$; $\left.98^{\circ} 13^{\prime} 10.9^{\prime \prime} W\right)$}

This outcrop was discovered by Esquivel-Macías et al. (2005). It is 30 meters wide and 26 meters high, with beds tilted at about $30^{\circ}$. It is a typical outcrop of very fine laminated sandy siltstones of the US (Arenas-Islas et al., 2009) with flasser and wavy sedimentary structures (Esquivel-Macías et al., 2005), corresponding to the Despí Fm. (sensu Schmidt-Effing, 1980). It shows an alternation of tafofacies 1, 2, and 3. The beds bear tiny columnar plates of pseudoplanktonic echinoderms.

The beds are Late Sinemurian in age, given the presence of $P$. aff. mexicanum, $P$. rothpletzi (Figure 10d), O. cf. incaguasiense, Coroniceras? aff. conybeary (Metophioceras), Phylloceras sp. (Figure 10e), Sul- ciferites cf. stenorhynchus (Lange, 1951), [Angulaticeras Quenstedt, 1883], reported in Esquivel-Macías et al. (2005), and O.jamesdanae. This set comprises a range centered in the Raricostatum zone, despite the presence of the Obtusum zone, since it includes Phylloceras sp. (Meister et al., 2005), which serves to prove its location in subzone denotatus. However, proper index of the Obtusum interval has not been found in this outcrop (Figure 7 ). In the raricostatum subzone, the rothpletzi horizon is the most representative; thereby it correlates almost exactly with the LA FIESTA outcrop. Here, there are many common taxonomic elements with T/V 4, T/V 6 TEN 1, TEN 3, TEN 7, LA FIESTA, POTRERO and PEÑA BLANCA, and BOPO 4 and 5.

\subsection{DAY 2}

2.2.1. STOP 1 TEMASCALAPA (20²2'06.3" N; 98 ${ }^{\circ} 12^{\prime} 52.1^{\prime \prime}$ W)

At TEMASCALAPA, there is a rhythmic sequence of sandy siltstone/quartzitic sandstone of the decimeter order. Schlatter and Schmidt-Effing (1984) regarded it as the Temascalapa Formation, although now there is geochemical evidence that it is just a slope facies of the Huayacocotla Fm. deposited at moderate depths (Angeles-Cruz, 2006). It is only recently that poorly preserved echioceratids were found here. The outcrop will be visited in order to find fossils, which may confirm this. Therefore, the attendees will be asked to inform the leaders about any fossils useful in documenting this facies as belonging to the Huayacocotla Fm.

\subsubsection{STOP 2 TEN-RÍO/LAS JUNTAS (20²1'54.09” N; $98^{\circ} 13^{\prime} 40^{\prime \prime}(W)$}

This outcrop is on the pond produced by Despí, Pantepec and Camarones River mouths, where the Pantepec River begins. The fossiliferous shales with subtle stratification, which look deformed and slaty, belong to Las Juntas Fm. (Schlatter and Schmidt-Effing, 1984). Currently, they are considered a Huayacocotla Fm. facies (Esquivel-Macías et al., 2014) especially taphofacies 1 (Esquivel-Macías et al., 2005, 2014). This represents an anoxic bottom where pyrites often originate, which means it 


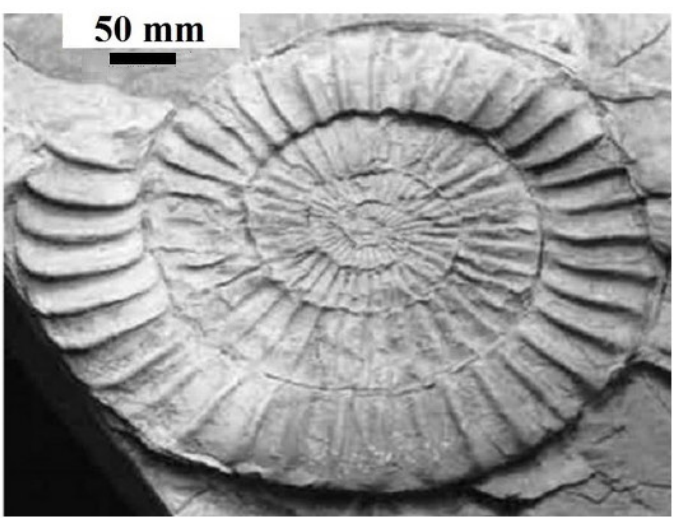

a

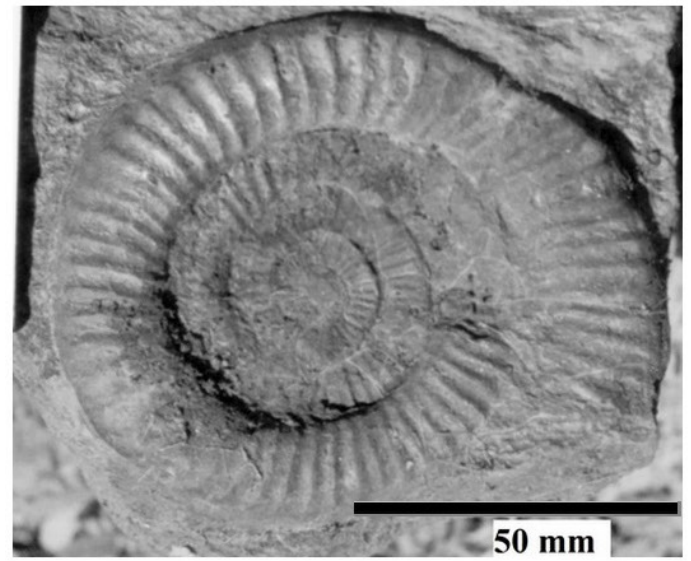

C

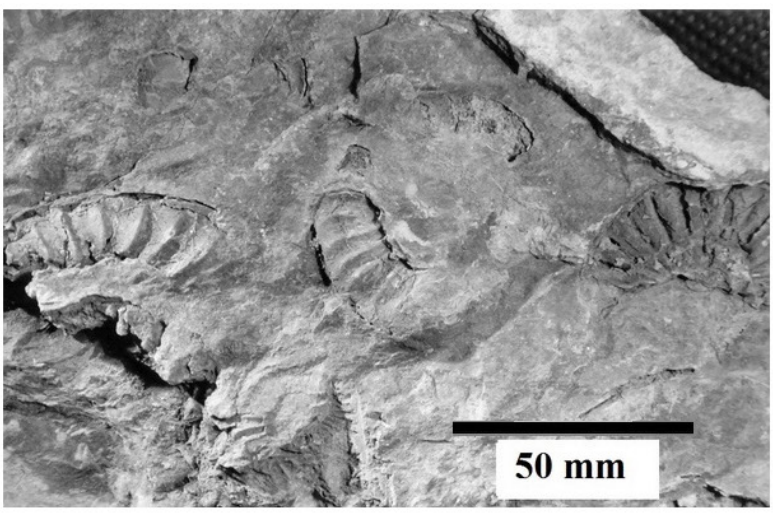

b

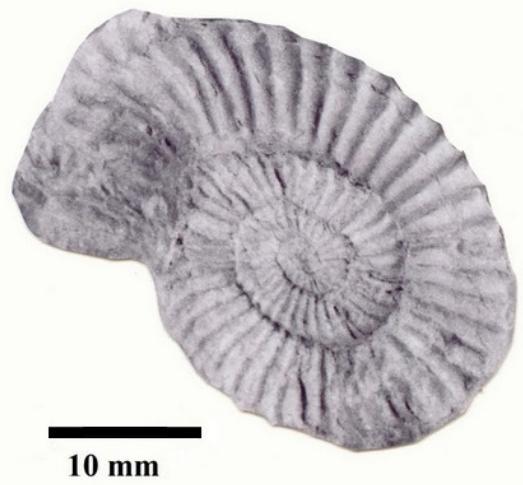

d

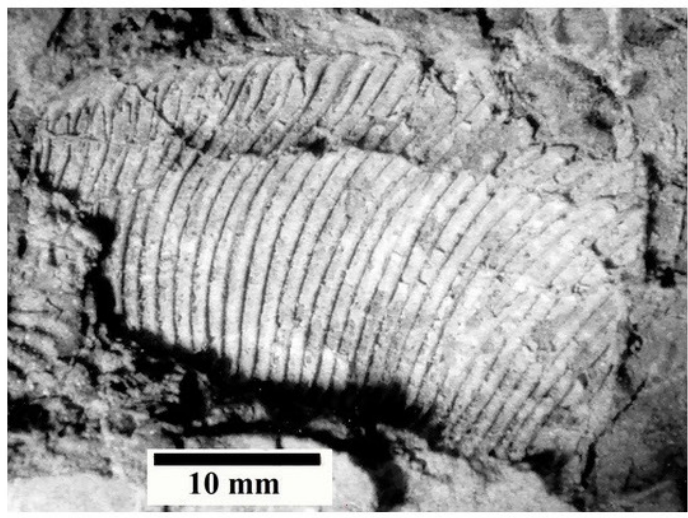

$\mathbf{e}$

Figure 10 Examples of the fauna of Huayacocotla: a) Paltechioceras aff. mexicaum (Erben, 1956) from Temapá outcrop; b) Ortechioceras jamesdanae (Trueman and Williams, 1925) from Peña Blanca outcrop; c) Paltechioceras hardbledownense (Crickmay, 1929-1930) from Bopo outcrops; d) Paltechioceras rothpletzi (Böse, 1898) from Chipotla outcrop; e) Phylloceras sp. (Suess, 1866) from La Fiesta outcrop. 
is the most distal facies of the Huayacocotla Fm. This is the only sampled outcrop which has the fauna of Early Sinemurian age (LS), given the dominant presence of: Arnioceras sp. (Hyatt, 1867) (Figure 12a), Arnioceras ceratitoides (Hillebrandt, 1981), Arnioceras miserabile (Quenstedt, 1883-1885), and Juraphyllites nardii (Meneghini, 1853), which were described as components of the Huayacocotla Fm. (Erben, 1956). Metophioceras conybeari (Sowerby, 1816), Calliphylloceras sp. (Spath, 1927), Metophioceras (?) anaberthae (Meister et al., 2002), Metophioceras molineroi (Meister et al., 2005), Partschiceras sp. (Fucini, 1923), and Arnioceras aff. oppeli (Guérin-Franiatte, 1966) were reported by Meister et al. (2002, 2005). The biostratigraphy reported by Meister et al. (2005) indicates an age range within the Lower Sinemurian centered in Bucklandi zone and including the lower Obtusum zone (Figure 7), which is the upper limit recognized by Meister et al. (2005), although Partschiceras sp. extends beyond the Upper Sinemurian till the Raricostatum zone. These authors considered that the chronostratigraphic weight of the faunistic set does not exceed the obtusum subzone. As a result, there is a reasonable doubt if Partschiceras may not actually correspond to this stratigraphic level, either because the quality of the material did not allow an accurate determination or because this genus is calling the attention to a possible homotaxial phenomenon which involves taxonomic elements of the Lower Sinemurian extending to the Upper Sinemurian, generating a geographical distribution artifact. This outcrop has common elements with TEMAPA, LA FIESTA, POTRERO and BOPO 4, as Plesechioceras, Arnioceras ceratitoides, $M e^{-}$ tophioceras, Coroniceras, and Phyloceras.

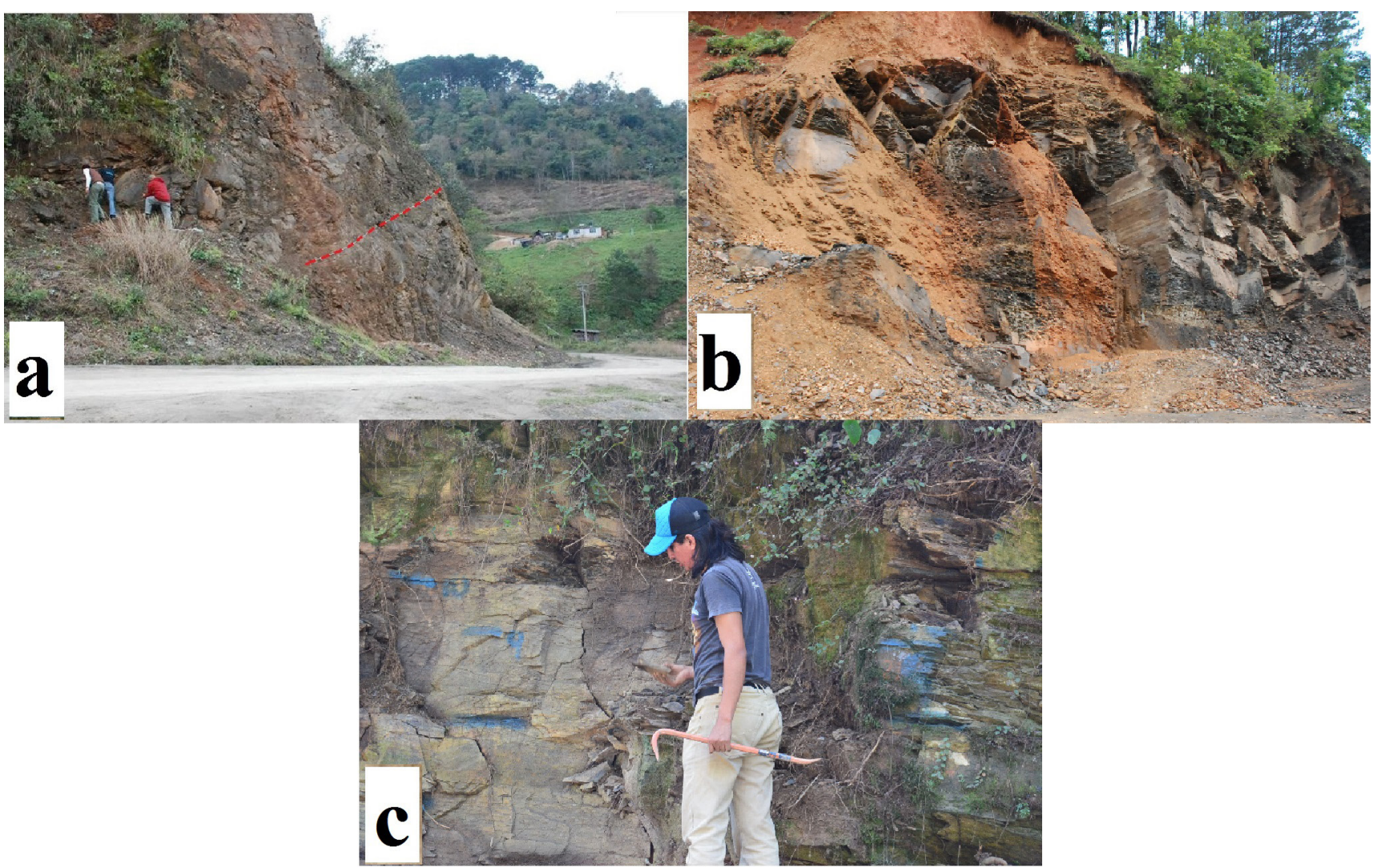

Figure 11 Some outcrops to be seen in the trip: a) Bopo 3 upper part and a lower part. The dashed red line marks the interpreted fauna change; b) Lower Jurassic rocks in Peña Blanca outcrop, a very productive outcrop from the Upper Sinemurian in the Tenango de Doria / San Bartolo locality; c) Potrero outcrop, Despí facies. This facies shows a subtle sedimentary condensation due to an alternation of the very fine sandstone-siltstone layers. 


\subsubsection{STOP 3 PEÑA BLANCA (20²3'54.4” N; 98 ${ }^{\circ} 14$ '56” W)} PEÑA BLANCA is a typical outcrop (Figure 11b) belonging to the US, with sandy laminated siltstones, according to the presence of: P. tardecrescens, P. rothpletzi, P. mexicanum, O. incaguasiense (Figure 12b), O. pauper, and Phylloceras sp. Many of these species are focused in the Raricostatum zone, aplanatum to densinodulum subzones, probably dominated by the raricostatum subzone (Meister et al., 2005, figure 3), with the favrei and licence/rothpletzi horizons, although the vertical distribution of $P$. rothpletzi have been very narrow (Figure 7).

The obvious continuity and lithological uniformity with the Despí Fm. is clear, but for only a few meters of thickness $(25 \mathrm{~m})$. The outcrop shows common taxa with T/V 5, T/V 6, TEN1, TEN 2, TEN 3, LA FIESTA, CHIPOTLA, and TEMAPA, which are also centered around the Upper Sinemurian (Esquivel-Macías et al., 2005; Meister et al., 2005, figure 2; Granados-León, 2007; Hernández-Velázquez, 2007).

\subsection{DAY 3}

\subsubsection{STOP $1 \mathrm{HONEY}\left(20^{\circ} 15 " 34.40^{\prime \prime} \mathrm{N}\right.$; 98 911 "31.19” W)}

Contreras and Núñez (1984) reported the presence of Aegyloticeras sp. (sensu Geyeria), Geyeria serorugata, Oxynoticeras sp., G. chofatti (Eparietites), Pompeckj, 1907; Paltechioceras bavaricum pauper (Ortechioceras pauper), Gleviceras sp., P. rothpletzi, Oxynoticeras aff. Victori, Paltechioceras bosei aff. vinascoi, Arnioceras monjeslopezi, Arnioceras abjectum, and Vermiceras vinascoi in this region. However, many of them are still in doubt according to the conclusions of the same authors (Figure 7). Besides, in the report of Erben (1956), the last three taxa of Arnioceras and Vermiceras have unclear stratigraphical provenance.

There are some doubts about the formal zoning of the Sinemurian in this region, based on the observations of Contreras and Núñez (1984), because they do not specify coordinates, maps or repositories. The main query the authors solved is the supposed presence of Arnioceras and Geyeria (Aegyloticeras), a fact that Erben (1956) dismissed as an invalid determination in the study zone. Thus, it will be accepted that, in the area of study the Lower Sinemurian was not settled, as indicated by the absence of characteristic ammonoids and also because the Upper Sinemurian ammonoid beds lie in direct contact with the Upper Triassic red beds (Contreras and Núñez, 1984).

\subsubsection{STOP 2 POTRERO (20 $16^{\prime} 40.9^{\prime}{ }^{N}$; $\left.98^{\circ} 10^{\prime} 21.3^{\prime \prime} W\right)$}

Potrero shows a 5-meter section, whose layers lie horizontally (Figure 11c). The sedimentation has produced decimeter strata of silty sandstone, generated by the regular accumulation of very fine sandy siltstone (Hernández-Velázquez, 2007). It belongs to the Late Sinemurian age, given the index species: $P$. rothpletzi, $P$. harbledownense, $P$. cihuacoatlae (Figure 12c), and Arnioceras sp. (Hyatt, 1867). All of them are assigned to the Late Sinemurian age, the Raricostatum zone, densinodulum to aplanatum subzones, probably raricostatum centered subzone (Meister et al., 2005, figure 3), with the favrei and licence/rothpletzi horizons, thus they belong to the upper part of the Late Sinemurian (Figure 7). This outcrop presents common taxonomic elements with TEMAPA, PEÑA BLANCA, LA FIESTA, CHIPOTLA, HONEY, TEN 1, TEN 3, TEN-RÍO/LAS JUNTAS, T/V 4, and BOPO 4 (see map in Blau et al., 2003; Meister et al., 2002, 2005, figure 2).

\subsubsection{STOP 3 CHIPOTLA $\left(20^{\circ} 16^{\prime} 21.6^{\prime \prime} N\right.$; 98 $\left.98^{\circ} 09^{\prime 2} 2.6^{\prime \prime} \mathrm{W}\right)$}

Rocks at this outcrop have doubtless US age, according to the presence of $P$. rothpletzi and $P$. harbledownense, which assign a range in the Raricostatum zone, despite the presence of $G$. chofatti (Figure 12d) and Phylloceras sp. that would be related to the Obtusum and Oxynotum zones. Thereafter, the outcrop is probably focused on the raricostatum subzone due to the narrow range of $P$. rothpletzi (Meister et al., 2005, figure 3), within favrei and licence horizons. The lithological continuity of its five meters is consistent with the Despí Fm. (sensu Schmidt-Effing, 1980). The taxonomical elements of this region are common with HONEY, PEÑA BLANCA, TEMAPA, LA FIESTA, POTRERO, T/V 4, TEN 3, TEN 7 (Meister et al., 2005, figure 2; Granados-León, 2007; Hernández-Velázquez, 


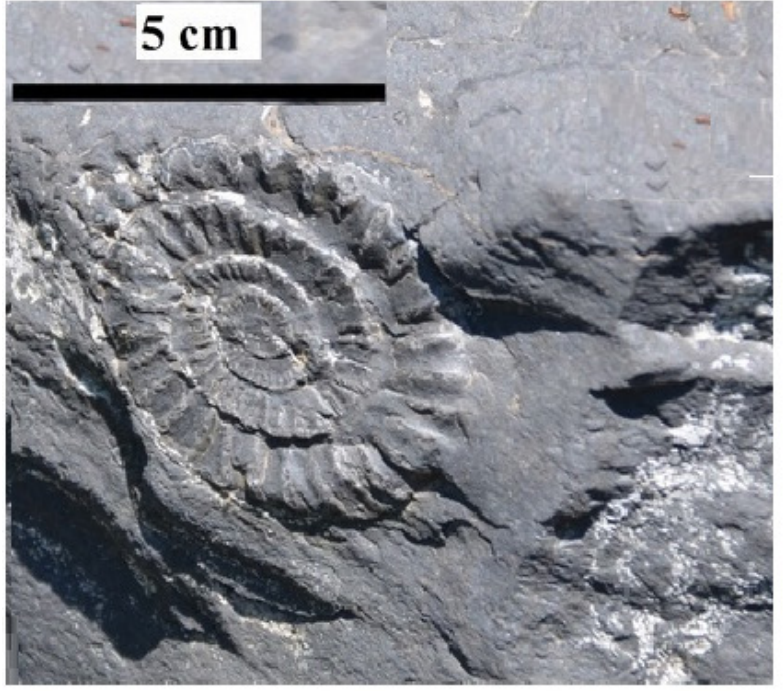

$\mathbf{a}$

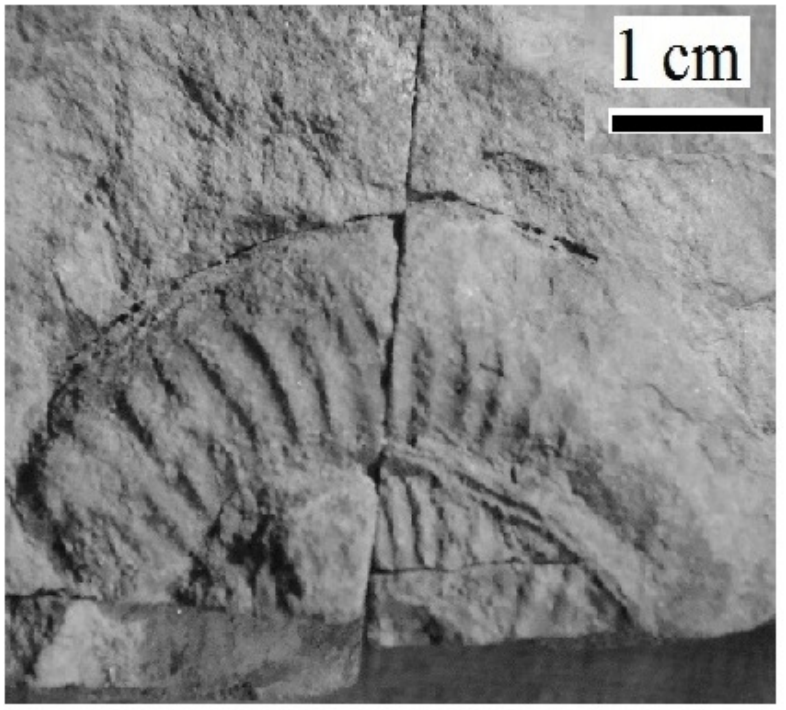

$\mathbf{c}$

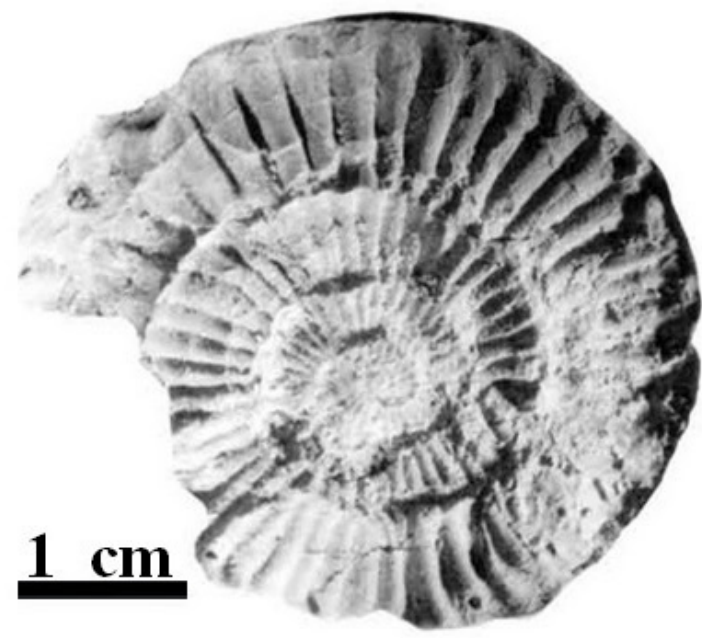

b

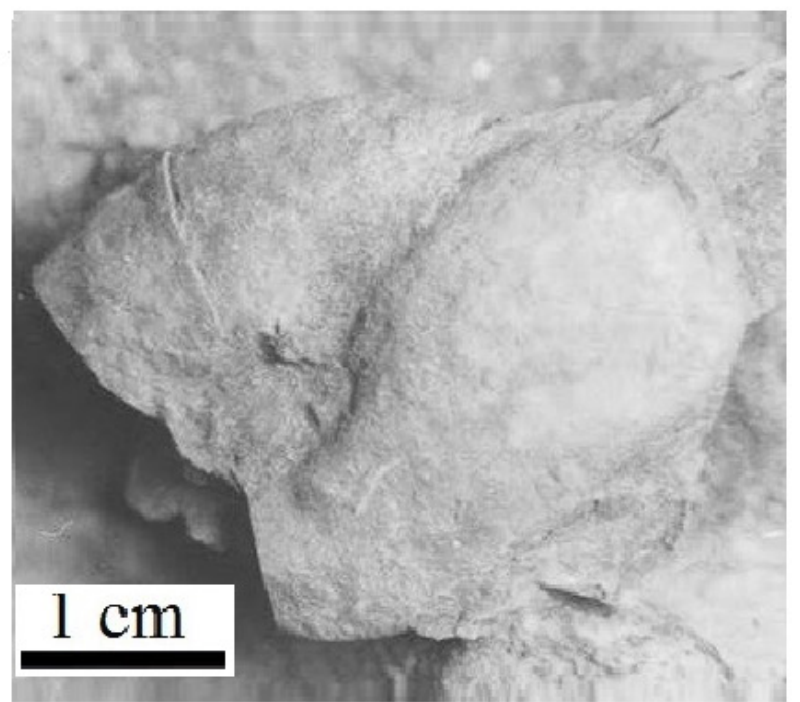

d

Figure 12 a) Arnioceras sp. (Hyatt, 1867) from Las Juntas outcrop; b) Ortechioceras incaguasiense (Hillebrandt, 2002) from La Fiesta outcrop; c) Plesechioceras cihuacoatlae (Erben, 1956) from Bopo 3 outcrop; d) Gleviceras chofatti (Buckman, 1913-1919) from Potrero outcrop. 
2007) (Figure 7).

\section{Complementary outcrops (not visited)}

This series completes the Huayacocotla Fm. biostratigraphical knowledge. At present, all of them confirm the existence of the "Interrupted Pattern", referred to above.

\subsection{T/V $4\left(20^{\circ} 19^{\prime} 56^{\prime}{ }^{\prime} \mathrm{N} ; 9^{\circ} 1^{\prime} 1^{\prime 46.9}{ }^{\prime}{ }^{\prime} \mathrm{W}\right)$}

First described by Schmidt-Effing (1977), this area does not have any new collections. It includes $E c^{-}$ tocentrites sp. (Canavari, 1888), originally described for the Lower Sinemurian of Vietnam in controversy with the report on T/V 4 by Blau et al. (2001), in the Upper Sinemurian beds. There is also Euerbenites corinnae (Blau et al., 2003), reported by Meister et al. (2005) and therefore, it belongs to the upper Obtusum zone and denotatus subzone. On the other hand, this outcrop includes components from the upper Oxynotum zone to the Raricostatum zone and raricostatum subzone, with Bifericeras tenangoense (Meister et al., 2002) and Gleviceras aztecorum (Meister et al., 2002). It also shows characteristics from the Oxynotum zone to the Raricostatum zone (Meister et al., 2005), based on the recorded appearance of Gleviceras aff. chollai (Taylor et al., 2001) (Figure 7).

\subsection{TEN $1\left(20^{\circ} 21^{\prime} 13.1^{\prime \prime} \mathrm{N} ; 9^{\circ} 13^{\prime} 17.3^{\prime \prime} \mathrm{W}\right)$}

Schmidt-Effing (1977) reported the presence of Arnioceras aff. ceratitoides (Quenstedt, 1883), sensu Prinz (1895), in the Semicostatum zone; Ectocentrites aff. domerguessi (Meister et al., 2002) was found in the Bucklandi/Semicostatum zone. However, this age assignation is controversial since it was first reported from the Lower Sinemurian of Vietnam. The case with Ectocentrites sp. may be the same. Euerbenites bravoi (Tilmann, 1917) is reported from the Obtusum/Denotatus zones while $E$. corinnae is reported from the same two zones, but Blau et al. (2001) consider that it reaches till the Raricostatum zone. This results in a false image of occupation of the complete Sinemurian. Other taxa in the same range are: Phylloceras sp. in the Denotatus zone, $O x y$ noticeras palomense (Erben, 1956) and P. cihuacoatlae (Erben, 1956) in the Raricostatum zone, densinodulum subzone, and edmundi horizon. Finally, in the aplanatum subzone the following taxa occur: P. tardecrecens and Plesechioceras sp. (Figure 7).

This fauna was reported by Meister et al. (2005), and partially by Blau et al. (2001, 2003), and Meister et al. (2002). They indicated that the fauna in this region had a range from bucklandi to raricostatum subzones including the "old collections" (Meister et al., 2005).

\subsection{TEN $3\left(20^{\circ} 21^{\prime} 24.59^{\prime}{ }^{\prime} \mathrm{N}\right.$; $\left.9^{\circ}{ }^{\circ} 3^{\prime} 17.39^{\prime}{ }^{\prime} \mathrm{W}\right)$}

This area suggests an interval from the Obtusum zone to the top of the Raricostatum zone due to the presence of: E. bravoi (Tilmann, 1917), E. corinnae (Blau et al., 2001), Euerbenites sp. (Blau et al., 2003), G. aztecorum (Meister et al., 2002), O. palomense (Erben, 1956), Gleviceras sp. (Erben, 1956), O. jamesdanae (Trueman and Williams, 1925), sensu Erben (1956), Oxinoticeras sp., P. (?), hardbledownense, P. cf. rothpletzi, P. tardecrecens, Partschiceras sp. (Fucini, 1923), and Phylloceras sp. (Suess, 1866) (Figure 7). Other outcrops with the same faunas are: POTRERO, TEMAPÁ, LA FIESTA, PEÑA BLANCA, BOPO 1, 2, 3, 4, and CENTRO.

\subsection{TEN $7\left(20^{\circ} 21^{\prime} 0.5^{\prime} \mathrm{N}^{\text {; }} 9^{\circ}{ }^{\circ} 3^{\prime} 19.1^{\prime}{ }^{\prime} \mathrm{W}\right)$}

This locality was first described by Schmidt-Effing (1977). It is very similar to the TEN 3 outcrop and shows: A. floresi (Erben, 1956), B. tenangoense (Meister et al., 2002), Ectocentrites sp. (Canavari, 1888), E. corinnae (Blau et al., 2001), G. aztecorum (Meister et al., 2002), Gleviceras choffati (Pompekj, 1907), and P. rothpletzi (Figure 7). Other outcrops with the same Upper Sinemurian fauna are: POTRERO, TEMAPA, LA FIESTA, PEÑA BLANCA, CHIPOTLA, BOPO 1, 2, 3 4, GENTRO, T/V 4, and TEN 3.

\subsection{ZONGOZOTLA $\left(19^{\circ} 59^{\prime} 50^{\prime \prime} \mathrm{N}\right.$; 9743’56” W)}

The description of Blau et al. (2008) mentions a 
lithological uniformity of this outcrop with the Despí Fm., given the presence of: $P$. gr. Burckhardti and P. mexicanum. While Gleviceras aff. palomense and Ectocentrites hillebrandtii are also reported by Blau et al. (2008), they are reported for the first time in the East-Central Mexico. The complete set ranges from the Oxynotum zone to the Raricostatum zone; however, it is possible to focus its location more accurately based on the subzones ranging from the raricostatum to the lower part of the aplanatum, which involves the aureolum horizon (Meister et al., 2005; Blau et al., 2008). It can be correlated with TEMAPA, T/V 6, PEÑA BLANCA, and BOPO 2, 3, 4, 5, and 6 (Figure 7).

\section{Discussion and conclusions}

In many outcrops, there is a shared pattern of concentration of Upper Sinemurian species, but it is also common to find some species whose range is reported to be in the Lower Sinemurian too. Also, there are many taxonomic records involving contradictory data regarding the Lower Sinemurian and practically none indicating directly the Obtusum zone.

The interrupted pattern is based on the outcrops that have a segment belonging to the LS Bucklandi zone (TEMAPA, LA FIESTA, BOPO 4, T/V 4, POTRERO, TEN 3, and TEN 7). There is also a group of outcrops (BOPO 1, BOPO 2, BOPO CENTRO, HONEY, CHIPOTLA, ZONGOZOTLA, BOPO 5 former T/V 6 (sensu Meister et al., 2002), and PEÑA BLANCA) that only yield US faunas. A couple of outcrops display two or three zones of the US (BOPO 3 and TEN 1), and TEN-RÍO/LAS JUNTAS displays exclusive taxa from LS. In Figure 11, a real gap can be seen marking the absence of index fossils from the MS or the Obtusum zone.

The material is so abundant and convincing that errors have been discarded ever since Erben (1956), although some individual determinations were based on low-quality material. Then, it becomes necessary to seek an explanation consistent with the interrupted pattern.

For example, at Temapá outcrop where Phylloceras appears, there are certain species that assign it to the topmost Sinemurian. Nevertheless, the presence of Coroniceras (Metophioceras) of the Lower Sinemurian contradicts this and makes it consistent instead with the TEN-RÍO/LAS JUNTAS outcrop, where the Lower Sinemurian age was reported and confirmed, and could even reach upper Hettangian. However, this same anomaly also arises at the LA FIESTA outcrop, with Lower Sinemurian taxa, but none is recorded to fill the "gap" between the latter and the Raricostatum zone. This situation may not be due to taphonomic effects, like the Time Averaging effect, given the work already carried out in the same outcrops (Arenas-Islas, 2012; Esquivel-Macías et al., 2014).

The condensation implies a change of zones, subzones, horizons and ages. Nevertheless, the lithology does not allow to assume any condensation to explain the entire Sinemurian range in several outcrops, except the Obtusum zone. Then, the alternative is that $P$. rothpletz $i$ and other ortechioceratids have a wider range than reported. But given its possible local origin (high endemism), this looks unlikely.

Given such patterns, the possible presence of an ecological barrier around the Huayacocotla basin during the lower Obtusum zone cannot be dismissed, although it is improbable due to the lithological continuity and the small thickness of the outcrops. Another likely explanation is that the stratigraphic range could be due to a combination of homotaxial events, related with the Pacific realm, although it should be focused on the Upper Sinemurian. A special controversy emerges with Ectocentrites, which was reported from Vietnam by Meister et al. (2002) and later at Zongozotla (Meister et al., 2005). This suggests that it entered the Huayacocotla paleobasin during the Upper Sinemurian after spreading from its origin in the Western Pacific.

The uncertainty about this idea includes the possibility that the paleocorridor, which introduced such Lower Sinemurian fauna from the Pacif- 
ic realm (sensu Westermann 2000a, 2000b), may have been intermittent, since only the TEN-RÍO/ LAS JUNTAS outcrop had this fauna. Also, the fauna should persist until the Upper Sinemurian without leaving any record in the lower Obtusum zone, because no other outcrop shows index-fossil evidences for that interval. This pattern could be explained considering endemism.

Finally, most outcrops are comparable to TEN 1 because surely it is centered also on the Upper Sinemurian and its lower part corresponds with the Hettangian-Lower Sinemurian. However, this seems unlikely too because the same lithological continuity and small thickness represented here do not let evident zonation change.

\subsection{INTERNATIONAL CORRELATION}

Northwestern Europe supports the standard zoning of the Lower Jurassic. Considering the Jurassic tectonic status, this region should have been much closer to the Huayacocotla Formation then, than it is today.

Starting with Dorset and Yorkshire in the coast of England (Bloos and Page, 2002), the Bucklandi and Obtusum zones are present, with homonymous subzones and horizons, supported by Arnioceras, Coroniceras, Metophioceras, and Vermiceras. In the same paper, there is a mention of Microderoceras, probably as an isolated homotaxial event, also mentioned by Erben (1956), for the Upper Sinemurian, but not in East-Central Mexico. Otherwise, the pattern is clear to denote the Lower Sinemurian in both locations and thus, it could be argued that both places are part of the region of origin and dispersion center of these taxa from East-Central Mexico.

Upper Sinemurian taxa in England-Angulaticeras, Oxynoticeras, Gleviceras, Eoderoceras, Echioceras, and Paltechioceras-coincide with those of East-Gentral Mexico, but these include more time than in England within the same range. This might suggest either that this part of Mexico acted as a dispersal center for some of the fauna after the break of some kind of a geographic isolation, or that at least Mexico was the corridor of these faunas to England.
For this part of Britain, the extreme ranges and the rather questionable presence of Arnioceras and Angulaticeras suggest that Obtusum zone was included, which is not represented in East-Central Mexico. Thus, in southwest England the correlation is very accurate with the Bucklandi zone and conybeari subzone, based on the presence of Vermiceras, $M e^{-}$ tophioceras and Coroniceras.

The correlation is clear with the entire Raricostatum zone from Germany at Herfor-Diebrock (Blau et al., 2000) based on the presence of Echioceras, Eoderoceras, Gleviceras and Paltechioceras. It could be suggested that both localities were connected, without being clear in what sense they would have moved or expanded.

In Portugal, considering the section at San Pedro Moel, both the oxynotum and raricostatum subzones are represented, resembling the outcrops of Central Mexico, based on the finding of P. rothpletzi, P. tardecrecens and Gleviceras sp. (Dommergues et al., 2010; Comas-Rengifo et al., 2013). But the high endemism of the Obtusum zone at San Pedro Moel separates it clearly from the Sinemurian upper part at that locality, and contrasts it with the complete Sinemurian range at North America, South America, and the rest of Europe. This reveals that a sedimentation gap is also possible (as an ecologic barrier) between the top Obtusum and Bucklandi zones in East-Central Mexico. Such a situation would be a case totally opposed to a faunal corridor.

Vietnam is representative of the paleo-Pacific Realm. The Bucklandi zone is present with E. domerguessi, also described in Mexico, and Vermiceras and Arnioceras (Meister et al., 2002). Therefore, this could be a source of dispersal of the fauna of the Lower Jurassic if a homotaxial phenomenon is invoked. This would involve Mexico and may have happened simultaneously in Europe, via para-Tethys, in the case that a barrier existed during the Obtusum zone between Northwestern Europe and Mexico, as suggested by the Portuguese fauna. The lower Obtusum zone with Arnioceras semicostatum, as occurring in Europe, refers to a lack of MS, as in East-Central Mexico, maybe due to the same 
cause, which prevented the dispersion to Mexico. In South America, with regard to Pacific bivalve fauna, the communication and dispersion toward Europe since the Hettangian to the Pliensbachian was clear (Damborenea and Manceñido, 1979; Aberhan, 1994, 1998). With all this, it seems that at least this region of the Pacific had fewer disruptions of dispersion with Mexico, and also with Europe, which also shows the full range of the Sinemurian. Thus, perhaps the idea of the Hispanic paleocorridor should be of a multiple corridor.

It is difficult to know how these groups of ammonoids were dispersed, unless the so-called LS fauna from Mexico arrived when the barrier with the Pacific broke during the US, and its fauna entered during the MS interruption in the Obtusum zone and during a prior LS communication in the Bucklandi and Semicostatum zones. All this points to a temporary isolation of the MS in East-Central Mexico and would explain the many siliciclastic rocks in this area without the fossils in the region (Damborenea and Manceñido, 1979, 1988, 2005; Damborenea, 1987, 2000; Aberhan, 1993).

In Canada, at Queen Charlotte Islands, B.C. (Pálfy et al., 1994), all the Sinemurian characteristics are represented, so the idea of a temporary MS isolation in the Huayacocotla Fm. is emphasized. Queen Charlotte Islands also yielded Arnioceras and Furaphyllites. In Queen Charlotte Islands,

\begin{tabular}{|c|c|c|c|c|c|c|}
\hline \multirow{2}{*}{ 둰 } & \multicolumn{2}{|c|}{ NW EUROPE } & \multirow{2}{*}{$\begin{array}{c}\text { PORTUGAL } \\
\text { ZONE }\end{array}$} & \multirow{2}{*}{$\begin{array}{c}\text { VIETNAM } \\
\text { ZONE }\end{array}$} & \multirow{2}{*}{$\begin{array}{c}\text { FM. } \\
\text { HUAYACOCOTLA } \\
\text { EAST CENTRAL } \\
\text { MEXICO } \\
\text { ZONE }\end{array}$} & \multirow{2}{*}{$\begin{array}{c}\begin{array}{c}\text { QUEEN } \\
\text { CHARLOTTE } \\
\text { ISLAND }\end{array} \\
\text { ZONE }\end{array}$} \\
\hline & ZONE & SUBZONE & & & & \\
\hline \multirow{4}{*}{ 空 } & \multirow{4}{*}{ JAMESONI } & Jamesoni & & & & \multirow{3}{*}{ IMLAYI } \\
\hline & & Brevispina & & & & \\
\hline & & Polymorphus & & & & \\
\hline & & Taylori & & & & \multirow{2}{*}{ TETRASPIDOCERAS } \\
\hline \multirow{17}{*}{ 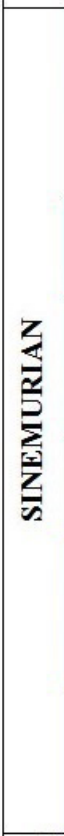 } & \multirow{4}{*}{ RARICOSTATUM } & Aplanatum & \multirow{4}{*}{ RARICOSTATUM } & & & \\
\hline & & Macdonelli & & & RARICOSTATUM & \multirow{5}{*}{ HARBLEDOWNENSE } \\
\hline & & Raricostatum & & & & \\
\hline & & Densinodulum & & & & \\
\hline & \multirow{2}{*}{ OXYNOTUM } & Oxynotum & \multirow{2}{*}{ OXYNOTUM } & & \multirow{2}{*}{ OXYNOTUM } & \\
\hline & & Simpsoni & & & & \\
\hline & \multirow{3}{*}{ OBTUSUM } & Denotatus & \multirow{3}{*}{ OBTUSUM } & & Denotatus & \multirow{3}{*}{ VARIANS } \\
\hline & & Stellare & & & & \\
\hline & & Obtusum & & & & \\
\hline & \multirow{2}{*}{ TURNERI } & Birchi & & & & \multirow{5}{*}{ ARNOULDI } \\
\hline & & Brooki & & & & \\
\hline & \multirow{3}{*}{ SEMICOSTATUM } & Sauzeanum & & \multirow{3}{*}{ SEMICOSTATUM } & \multirow{3}{*}{ SEMICOSTATUM } & \\
\hline & & Scipionianum & & & & \\
\hline & & Reynesi & & & & \\
\hline & \multirow{3}{*}{ BUCKLANDI } & Bucklandi & & \multirow{3}{*}{ BUCKLANDI } & \multirow{3}{*}{ BUCKLANDI } & \multirow[t]{2}{*}{ CORONICERAS } \\
\hline & & Rotiforme & & & & \\
\hline & & Conybeari & & & & \multirow[t]{2}{*}{ CANADENSIS } \\
\hline$\dot{\square}$ & ANGULATA & Complanata & & & & \\
\hline
\end{tabular}

Figure 13 International stratigraphic correlation compared with the stratigraphic range of Huayacocotla Fm. (H. Hettangian; PLIENS. Pliensbachian). 
the correlation of P. harbledownense, Echioceras and Gleviceras with US is clear, while Arnioceras sp. and Metophioceras sp. attest the presence of LS. Meanwhile, in localities in Yukon the LS presence is evident (Pálfy et al., 1999), but apparently there is no MS. Although Pálfy et al. (1994) proposed a zonation for North America based on the Queen Charlotte fauna (Figure 13), they also report the presence of complete Sinemurian interval, as in Europe.

\section{Acknowledgements}

We gratefully acknowledge Susana Damborenea from La Plata, Argentina for valuable and constructive comments on text. We also thank the three anonymous reviewers whose detailed observations and careful advice allowed us to notoriously improve the quality of the text. We thank Francisco Vega Vera, associated editor of BSGM, for his patient with the several versions of manuscript. We specially thank Ana Bertha Villaseñor for the invitation to participate in the current issue of BSGM and the original idea of a Field guide to Huayacocotla Formation, and indeed for her brilliant role in the organization of the " $10^{\text {th }}$ International Congress on Jurassic System, 2018” which is the motive of the current paper.

\section{References}

Aberhan, M., 1993, Benthic macroinvertebrate associations on a carbonate-clastic ramp in segments of the Early Jurassic back-arc basin of northern Chile (26-29 $\mathrm{S}$ ): Revista Geológica de Chile, 20(2), 105-136.

Aberhan, M., 1994, Early Jurassic Bivalvia of Northern Chile Part I. Subclasses Palaeotaxodonta, Pteriomorphia and Isofilibranchia: Beringeria: Zürich, Switzerland 13, 108 p.

Aberhan, M., 1998, Early Jurassic Bivalvia of Western Canada. Part I. Subclasses
Palaeotaxodonta, Pteriomorphia and Isofilibranchia: Beringeria: Zürich, Switzerland, 21, 57-150.

Aberhan, M., Muster, H., 1997, Palaeobiology of Early Jurassic Bakevellid Bivalves from Western Canada: Paleontology, 40, 799-815. Aberhan, M., Palfy, J., 1996, A low oxygen tolerant east pacific flat clam (Posidontis semiplicata) from the lower Jurassic of the Canadian cordillera: Canadian Journal of Earth Sciences, 33, 993-1006.

Aguayo-Camargo, J.E., 1977, Sedimentación y Diagénesis de la Formación "Chipoco" (Jurásico Superior) en afloramientos, estados de Hidalgo y San Luis: Revista del Instituto Mexicano del Petróleo, 9(2), 11-37.

Angeles-Cruz, C., 2006, Geoquímica de las rocas sedimentarias jurásicas en localidades fosilíferas de la Sierra Madre Oriental (Tenango de Doria-San Bartolo Tutotepec, Hidalgo): Implicaciones paleoambientales: Hidalgo, México, Universidad Autónoma del Estado de Hidalgo, Tesis profesional, 155 p.

Angeles-Cruz, G., Flores-Castro, K., EsquivelMacías, C., Armstrong-Altrim, J.S., Torres-Valencia, J.M., 2007, Presencia de Carotenoides aromáticos en rocas siliciclásticas de la Formación Huayacocotla (Jurásico Inferior), estados de Hidalgo y Puebla (México): Implicaciones paleoambientales utilizando biomarcadores, in XVII Congreso Nacional de Geoquímica, 1-6 Oct., 2007, Armstrong-Altrin, J.S., Flores-Castro, K., Cruz-Ortiz, L. (eds.), AGTAS INAGEQ, 164 p.

Arellano-Gil, J., Vachard, S.D., Yussim, D., Flores de Dios-González, A., 1998, Aspectos estratigráficos, estructurales y paleogeográficos del Pérmico Inferior al Jurásico Inferior en Pemuxco, Estado de Hidalgo, México: Revista Mexicana de Ciencias Geológicas, 15(1), 9-13.

Arenas-Islas, D., 2012, Análisis Tafonómico de rocas siliciclásticas del sinemuriano superior (Jurásico Inferior), en la Formación 
Huayacocotla, centro oriente de México: Hidalgo, México, Universidad Autónoma del estado de Hidalgo, Tesis de Maestría en Ciencias, $94 \mathrm{p}$.

Arenas-Islas, D., Esquivel-Macías, C., FloresCastro, K., 2009, Amonoideos y bivalvos del Sinemuriano Superior en un nuevo afloramiento de la Formación Huayacocotla, Hidalgo, México, algunas consideraciones paleoambientales: Boletín de la Sociedad Geológica Mexicana, 61(2), 185-197.

Bambach, R.K., 1983, Ecospace utilization and guilds in marine communities through the Phaneorozoic, in Tevesz, S.J.M., McCall, L.P. (eds.), Biotic Interactions in Recent and Fossil Benthic communities: New York, U.S.A., Plenum PRESS New York, 719-746.

Blau, J., Meister, C., 2000, Upper Sinemurian Ammonite Successions Based on 41 Faunal Horizons: an attempt at worldwide correlation: Geo-Research Forum, 6, 3-12.

Blau, J., Meister, C., Ebel, R., Schlater, R., 2000, Upper Sinemurian and Lower Pliensbachian ammonite faunas from Herford-Diebrock area (NW Germany): Palaeontologische Zeitschrift, 74(3), 259-280.

Blau, J., Meister, C., Schlatter, R., Schmidt-Effing, R., 2001, Ammonites from the lower Jurassic (Sinemurian), of Tenango de Doria (Sierra Madre Oriental, México), Part II: Erbenites n.g., a new Asteroceratinae: Neus Jahrbuch für Geologie und Palaontologie Monashefte, 3, 175-183.

Blau, J., Meister, C., Schlatter, R., SchmidtEffing, R., 2003, Ammonites from the lower Jurassic (Sinemurian), of Tenango de Doria (Sierra Madre Oriental, México), Part III: Echioceratinae: Revue Paleobiologie Géneve, 22(1), 421-437.

Blau, J., Meister, C., Schmidt-Effing, R., Villaseñor, A.B., 2008, A new fossiliferous site of Lower Liassic (Upper Sinemurian), marine sediments from the Southern Sierra Madre
Oriental (Puebla, Mexico), ammonite fauna, biostratigraphy, and description of Ectocentrites hillebrandti new species: Revista Mexicana de Ciencias Geológicas, 25(3),402-407.

Bloos, G., Page, K.N., 2002, Global Stratotype Section and Point for base of the Sinemurian Stage (Lower Jurassic): Episodes, 25(1), 22-28.

Böse, E., 1898, Ueber lias in Mexico: Zeitschrift der Deutschen Geologischen Gesellschaft, 50, 168-175.

Buckman, S.S., 1913-1919, Yorkshire Type Ammonites: the original descriptions reprinted, and illustrated by figures of the types, reproduced from photographs mainly by J.W. Tutcher, Vol. 1-2: London, Wheldon and Wesley, $452 \mathrm{p}$.

Burckhardt, G., 1930, Études synthétiques sur le Mesozoique Mexicain: Société Paleontologiqué Suisse, 49(50), 1-280.

Canavari, M., 1888, Contribuzione alla fauna de Lias inferiore di Spezia: Memorie del Regio Comitato Geologico Italiano, vol. 3, p. 57-227.

Cantú-Chapa, A., 1971, La serie Huasteca (Jurásico Medio-Superior), del centro este de México: Revista del Instituto Mexicano del Petróleo, 3(2), 17-40.

Cantú-Chapa, A., 1998, Las transgresiones Jurásicas de México: Revista Mexicana de Ciencias Geológicas, 15(1), 25-37.

Carrillo-Bravo, J., 1965, Estudio Geológico de una parte del Anticlinorio de Huayacocotla: Boletín de la Asociación Mexicana de Geólogos Petroleros, 17(5-6), 73-96.

Coe, A.L., Bosence, D.W.J., Church, K.D., Flint, S.S., Howell, J.A., Wilson, R.C.L, 2003. The sedimentary record of sea-level change: Cambridge, UK, The Open University, N. Y., Cambridge University Press, 288 p.

Comas-Rengifo, M.J., Duarte, L.V., Goy, A., Paredes, R., Silva, R.L., 2013, El Sinemuriano Superior (cronozaonas 
Oxynotum y Raricostatum), en la Región de S. Pero Moel (Cuenca Lusitanica, Portugal), Comunicações Geológicas 100 (especial 1), 15-19.

Contreras, B., Núñez, M., 1984, Estudio bioestratigráfico basado en amonitas de las rocas liásicas de Honey - Pahuatlán, Puebla, in Perriliat, M.C. (ed.), Memoria del III Congreso Latinoamericano de Paleontología: México, Instituto de Geología, UNAM, 156-164.

Craig, R.G., Kronen Jr., Symons, J.D., Wuchung, P.A., Kron D., 1993, High Resolution sequence stratigraphy, condensed sections and flooding events off the great barrier reef: 0-1.5 MA, in McKenzie, J.A., Davies, P.J., Palmer-Julson, A. (eds.), Proceedings of the Ocean Driling Program: Australia, Scientific Results, 133, 3-879.

Crickmay, C.H., 1929-1930, The stratigraphy of Parson Bay, British Columbia: University of California Publicationsin Geological Sciences, 18, 51-70.

Damborenea, S.E., 1987, Early Jurassic Bivalvia of Argentina. Part 2 Superfamilia Pteriacea, Buchiacea and part of Pectinacea: Paleontographica, 199, 113-216.

Damborenea, S.E., 2000, Hispanic Corridor: Its Evolution and the Biogeography of Bivalve Molluscs: Geo Research Forum, 6, 369-380.

Damborenea, S.E., Manceñido, M.O., 1979, On the paleogeographical distribution of the pectinidgenus Weyla (Bivalvia, Lower Jurassic): Paleogeography, Paleoclimatology, Paleoecology, 27, 85-102.

Damborenea, S.E., Manceñido, M.O., 1988, Weyla: Semblanza de un Bivalvo Jurásico Andino, in V Congreso Geológico Chileno: 8-12 Agosto de 1988, Santiago de Chile, Departamento de Geofísica y Geoquímica, Universidad de Chile, Tomo II: 16-25.

Damborenea, S.E., Manceñido, M.O., 2005, Biofacies analysis of the HettangianSinemurian bivalve / brachiopod associations from the Neuquén Basin, Argentina:
Geologica Acta, 3(2), 163-178.

Díaz-Lozano, E., 1916, Descripción de unas plantas liásicas de Huayacocotla, Veracruz. Algunas plantas de la flora liásica de Huahuchinago, Puebla: Instituto Geológico de México, Boletín, 34, 1-18.

Dommergues, J.L., Meister, C., Rocha, R.B., 2010, The Sinemurian ammonites of the Lusitanian Basin (Portugal), an example of complex endemic evolution: Paleodiversity, 3, 59-87.

Dueñas-García, J.G., Frías-González, M.A, Benítez-López, J., Macedo-Palencia, R., Rodríguez- Salinas, J.J. (comps.), 1992, Monografía Geológico Minera del estado de Hidalgo, Primera Edición, Consejo de Recursos Minerales, Pachuca, Hidalgo, Secretaría de Energía, 92.

Dumortier, E., 1867, Études paléontologiques sur les dépôts jurassiques du Bassin du Rhône. Deuxième partie: Lias inférieur, Paris, France, Savy, 1-252.

Erben, H.K., 1956, El Jurásico Inferior de México y sus Amonitas, in XX Congreso Geológico Internacional: México, Instituto de Geología, Universidad Nacional Autónoma de México, Instituto de Geología, 393.

Esquivel-Macías, C., 2003, Temapá, Hidalgo: A New Fossiliferous Outcrop from Lower Jurassic with Crinoids and Ammonoids on East Central Mexico, Paleoenvironmental Interpretation, in $99^{\text {th }}$ ANNUAL MEETING CORDILLERAN SECTION, 2003: USA, The Geological Society of America, 1-30 p.

Esquivel-Macías, C., León-Olvera, R.G., FloresCastro, K., 2005, Caracterización de una nueva localidad fosilífera del Jurásico Inferior con Crinoides y Amonites en el centrooriente de México (Temapá, Hidalgo): Revista mexicana de Ciencias Geológicas, 22(1), 97-114.

Esquivel-Macías, C., Flores-Castro, K., LeónOlvera, R.G., 2007, Paleoambiente y Composición de las asociaciones fósiles de moluscos en una localidad del Sinemuriano 
Superior de la región de Pahuatlán, Puebla, in Ríos-Jara, E.M., Esqueda-González, C., Galván-Villa, G.M. (eds.), Estudios sobre la malacología y Conquiliología en México: Guadalajara, México, Universidad de Guadalajara, 286 p.

Esquivel-Macías, G., Arenas-Islas, D., Flores-Castro, K., Mendoza, G., 2014, Caracterización de tafofacies en la Formación Huayacocotla, Jurásico inferior (Sinemuriano Superior), centro oriente de México: Revista Brasilera Paleontología, 17(2), 249-272.

Esquivel-Macías, C., Flores-Castro K., BravoCuevas V., León-Olvera, R.G., 2012, Paleoambiente de un afloramiento del Sinemuriano superior en la Formación Huayacocotla con base en atributos Tafonómicos: Revista Mexicana de Paleontología, 62(1), 73-91.

Felix, J., Lenk, H., Nathorst, A.G., Boehm, G., Steinmann, G., Hoppe, A., 1889-1899, Beiträge zur Geologie und Paläontologie der Republik Mexico: Leipzig, Germany, Verlag von Arthur Felix und E. Schweizerbart'sche Verlasgshandlung (E. Nagele), Vol. 3, 146 p.

Flores-Castro, K., Angeles-Cruz, C.A., Hernández-Hernández, A., Gibson, R., Ramírez- Cardona, M., Armstrong-Altrin, J.S., Esquivel-Macías, C., 2008, Condiciones de hipersalinidad, Anoxia y Naturaleza del Protolito en Rocas Jurásicas de la Región de Molango, Hidalgo (México): Interpretación con Biomarcadores: Isla Margarita, Venezuela, Latin American Association of Organic Geo Chemistry, 223-227.

Flores-Castro, K., Angeles-Cruz, C.A., TorresValencia, J.M., Armstrong-Altrin, J.S., Esquivel-Macías, C., 2006, Pristane/ Phytane ratio in Sinemurian siliciclastic Rocks from the Huayacocotla Group; State of Hidalgo, Mexico: Medellín, Colombia, Latin American Association of Organic Geochemistry Elsevier, 331, 214-217.

Fucini, A., 1923, Fossili domeriani dei dintorni di Taormina. Parte 1: Palaeontographica
Italica, 26(1920), 75-1 16.

Gayosso-Morales, M.A., 2007, Análisis

Paleoambiental Mediante Fósiles de Invertebrados del Jurásico Inferior (Sinemuriano), en la Localidad "EL BOPO", Estado de Hidalgo, México: Hidalgo, México, Universidad Autónoma del Estado de Hidalgo, Tesis Profesional, 136 p.

Granados-León, A., 2007, Interpretación de Paleoambientes Marinos del grupo Huayacocotla con base en invertebrados Fósiles en la Localidad "Peña Blanca". Municipio de San Bartolo Tutotepec, Hidalgo, México: Hidalgo, México, Universidad Autónoma del Estado de Hidalgo, Tesis Profesional, 62 p.

Guérin-Franiatte, S., 1966, Amonites du Lias inférieur de France. Psilocerataceae: Arietitidae: Paris, France, CNRS édit, 455 p.

Hauer, F., von, 1856, Über die Cephalopoden aus dem Lias der nordöstlichen Alpen: Denkschriften der Kaiserlichen Akademie der Wissenschaften en Wien : MathematishNaturwissenchaftliche, 11, 1-86.

Hernández-Velázquez, J.E., 2007, Interpretación de paleoambientes del Sinemuriano Superior (Jurásico Inferior), del Grupo Huayacocotla en la región de Pahuatlán, Puebla: Hidalgo, México, Universidad Autónoma del estado de Hidalgo, Tesis Profesional, 123 p.

Hillebrandt, A. von, 1981, Faunas de amonitas del Liásico Inferior y Medio (Hettangiano hasta Pleisbachiano) de América del Sur (excluyendo Argentina), in Cuencas sedimentarias del Jurásico y Cretácico de América del Sur: Buenos Aires, Argentina W. Volkheimer and E.A. Musacchio (eds.), COMITÉ SUDAMERICANO DEL JURÁSICO: 2, 499-537.

Hillebrandt, A. von, 2002, Ammoniten aus dem oberen Sinemurian von Sudamerika: Revue de Paléobiologie, 21(1), 35-147.

Hyatt, A., 1867, The fossil Cephalopods of the museum of comparative Zoology: Bulletin of the Museum of Comparative Zoology, I(5), 
71-102.

Imlay, R.W., Cepeda, E., Álvarez, M., DíazGonzález, T., 1948, Stratigraphic relations of certain Jurassic formations in eastern Mexico: American Association of Petroleum Geologist Bulletin, 32(9), 1750-1761.

Landman, N.H., Tanabe, K., Davis, R.A. (eds.), 1996, Ammonoid Paleobiology: New York, U.S.A., Plenum Press, 857 p.

Lange, W., 1951, Die Schloteimiidae aus dem Lias alpha nord-deutschland: Palaeontográphica A, 100, 1-128.

López-Ramos, E. 1979, Geología de México: México, Volumen III: 446 p.

McKerrow, W.S., 1978, The ecology of fossils, An illustrated guide: Massachusetts, U.S.A., The MIT Press Cambridge, 381 p.

Meister, C., Blau, J., Domergues, J.L., Schlatter, R., Schmidt-Effing, R., Burk, K., 2005, Ammonites from the Lower Jurassic (Sinemurian), of Tenango de Doria (Sierra Madre Oriental, Mexico). Part IV: bioestratigraphy, palaobiogeography and taxonomic adendum: Revue Paleobiologie, 24(1), 365-384.

Meister, C., Blau, J., Schlatter, R., SchmidtEffing, E., 2002, Ammonites from the Lower Jurassic (Sinemurian), of Tenango de Doria (Sierra Madre Oriental, Mexico). Part II: Phylloceratoidea, Lytoceratoidea, Schloteimiidae, Arietitinae, Oxinoticeratidae, and Eoderoceratidae: Revue de Paléobiologie, 21(1), 391-409.

Mendoza-Rosales, G., Arellano-Gil, J., SilvaRomo, G., 1992, Nuevas localidades del contacto transicional de las formaciones Huizachal y Huayacocotla, in Convención Geológica Nacional 11: Veracruz, México, Sociedad Geológica Mexicana, 121.

Meneghini, G., 1853, Nuovi fossili toscani illustrate dal Prof. G. Meneghini. Appendice alle considerazioni sulla geologia stratigrafica toscana dei Professori Cavaliere P. Saavi e G. Meneghini: Annali dell' Universita Toscana,
$3,1-40$.

Ochoa-Camarillo, H.R., 1997a, Geología del Antclinorio Huayacocotla en la región de Molango, Hidalgo, México, in GómezCaballero, A., Alcayde-Orraca M. (eds.), II Convención Sobre la Evolución Geológica de México y Recursos Asociados, Pachuca, Hidalgo, México: Universidad Autónoma del Estado de Hidalgo, Instituto de Investigaciones en Ciencias de la Tierra, Instituto de Geología de la UNAM, Guía de las excursiones Geológicas, 1-17.

Ochoa-Camarillo, H.R., 1997b, Aspectos bioestratigráficos, paleoecológicos y tectónicos del Jurásico (Anticlinorio de Huayacocotla), en la región de Molango, Hidalgo, in Gómez-Caballero, A., AlcaydeOrraca, M. (eds.), II Convención Sobre la Evolución Geológica de México y Recursos Asociados, Pachuca, Hidalgo, México: Universidad Autónoma del Estado de Hidalgo, Instituto de Investigaciones en Ciencias de la Tierra, Instituto de Geología de la UNAM, Guía de las excursiones Geológicas, Symposia y Coloquio, s/p.

Pálfy, J., Smith, P.L., Tipper, H.W., 1994, Sinemurian (Lower Jurassic), Ammonoid biostratigraphic of the Queen Charlotte Islands, Western Canada: Geobios, 17, 385-393.

Pálfy, J., Smith, P.L., Mortensen, J.K., Friedman, R.M., 1999, Integrated ammonite biochronology and $\mathrm{U}-\mathrm{Pb}$ geochronometry from a basal, Jurassic section in Alaska: Geological Society of America Bulletin, 111(10), 1537-1549

Pedrazzini, C., Bazañez-Loyola, M.A., 1978, Sedimentación del Jurásico Medio-Superior en el anticlinorio de Huayacocotla-Cuenca de Chicontepec, Estados de Hidalgo y Veracruz, México: Revista del Instituto Mexicano del Petróleo, 10(3), 6-25.

Pettijohn, F.J., 1975, Sedimentary rocks, 3rd Edition: NewYork, U.S.A., Harper and Raw 
Publishers, $614 \mathrm{p}$.

Pompeckj, J.F., 1907, Notes sur les Oxinoticeras du Sinémurien Superieur du Portugal et remarques sur le genre Oxynoticeras; Serviços Geológico de Portugal Comunicações Commission, 6, 2214-38.

Prinz, P., 1985, Stratigraphie und Ammonitefauna der Pucará-Grouppe (Obertrias-Unterjura) von Nord-Peru: Palaeontographica, 188(46), 153-197.

Quenstedt, F.A., 1883-1885, Die amoniten des SchwaebischenJura.Pte. 1,DerSchwartzeJura (Lias): Stutgart, Deutschland,Schweizerbart, $440 \mathrm{p}$.

Rosenberg, P., 1909, Die liasische Cephalopodenfauna der Kratzalpe im Hagengebirge: Beiträge zur Paläontologie Österreich-Ungarns und des Orients, 22, 193-345.

Rueda-Gaxiola, J., Dueñas, M.A., Rodríguez, J.L., Minero, M., Uribe, G., 1993, Los anticlinorios de Huizachal-Peregrina y de Huayacooctla; dos partes de fosa de Huayacocotla: Boletín de la Asociación Mexicana de Geólogos Petroleros, 43(2), 1-296.

Schlatter, R., Schmidt-Effing, R., 1984, Bioestratigrafía y fauna de amonites del Jurásico Inferior (Sinemuriano), del área de Tenango de Doria (estado de Hidalgo, México), (memorias), in 3er. Congreso Latinoamericano Paleontología: Oaxtepec, Morelos, México, Instituto de Geología, Universidad Nacional Autónoma de México, 154-156.

Schmidt-Effing, R., 1977, Der marine Unterjura Mexikos. Stratigraphie und Verbreitung sowie seine Bexiehungen zur Entstehung des Golfes von Mexiko: Münster, Westfälische Wilhelms-Universität, Habilitationsschr, 157. Schmidt-Effing, R., 1980, The Huayacocotla Aulacogen in Mexico (Lower Jurassic), and the origin of the Gulf of Mexico, in Pilger, R.H. Jr. (ed.), Symposium on The Origin of the Gulf of Mexico and the early opening of the central North Atlantic, Proceedings:
Baton Rouge, USA, Lousiana State University, 79-86.

Sedlock, R., Ortega-Gutiérrez, L.F., Speed, R.G., 1993, Tectono-stratigraphic Terraines and Tectonic Evolution of Mexico: Special Paper 278 Geological Society of America,Boulder, Colorado, USA 161 p.SERVICIO GEOLÓGICO MEXICANO (SGM), 2004, Carta geológico minera Pahuatlán F14 D73, 1:50000: Pachuca, Hidalgo, México, Secretaría de Economía, 1 mapa con texto.

Silva-Pineda, A., 1978, Paleobotánica del Jurásico de México-Contribuciones a la Paleobotánica del Jurásico de México: Paleontología Mexicana, 44(1), 1-16.

Sowerby, J., 1816, Mineral Conchology of Great Britain: London, Meredith, 1-4.

Spath, L.F., 1923, The ammonites of the "Shaleswith-beef", Pte.2, Paleontology: Quarterly Journal of the Geological Society, 79, 66-68, 3-4 plates.

Spath, L.F., 1927-1933, Revision of the Jurassic Cephalopod fauna of Kachh (Kutch), Palaeontologia Indica, Geological Survey of India,Calcutta, 9(2), 1-945.

Suess, E., 1866, Ubber Ammoniten:Wien, Kaiserlichen Akademie der Wissenschaften, Sitzungverichte der Mathematissch naturwissenschftliche Classek, Abt. 1, Band $52,71-89$.

Suter, M., 1980, Tectonics of the external part of the Sierra Madre Oriental foreland, thrust and fold belt between Xilitla and Moctezuma river (Hidalgo and San Luis Potosí states, Mexico: Instituto de Geología Revista, Universidad Nacional Autónoma de México, 4,19-31.

Taylor, D.G., Guex, J., Rakus, M., 2001, Hettangian and Sinemurian ammonoids zonation for the Western Cordillera of North America: Bulletin of Géologie de l'université de Lausanne, 350, 381-405.

Tilmann, N., 1917, Die Fauna des unteren und mittleren Lias in Nord- und Mittel-Peru: Neues Jahrbuch für Mineralogie, Geologie 
und Paläontologie, Beilageband, 41, 628-712.

Trueman, A.E., Williams, D.M., 1925, Studies in the ammonites of the family Echioceratidae: Transactions of the Royal Society of Edinburgh, 53, 699-739.

Westermann, G.E.G., 1996, Ammonoids Life and Habitat, in Landman, N.H., Tanabe, K., Davies, R.A. (eds.), Ammonoid Paleobiology: New York and London, Plenum Press, 607-739.

Westermann, G.E.G., 2000a,Biochoreclassification and nomenclature in paleobiogeography: an attempt at order: PALAEO, 158, 1-13.

Westermann, G.E.G., 2000b, Marine faunal realms of the Mesozoic: Review and revision under the new guidelines for biogeographic classification and nomenclature: PALAEO, 163, 49-68.

Westermann, G.E.G., 2004, The Jurassic of the Circum-Pacific: Cambridge, Cambridge University Press, Series World and Regional Geology 3, 100-101. 